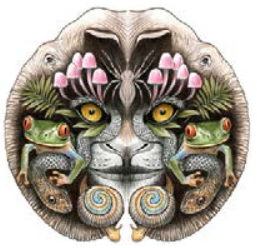

ISSN 0974-7907 (Online) ISSN $0974-7893$ (Print)

OPEN ACCESS

\title{
TAXONOMIC STUDIES ON VESPID WASPS (HYMENOPTERA: VESPOIDEA: VESPIDAE) OF CHHATTISGARH, INDIA
}

\author{
P. Girish Kumar ${ }^{1} \&$ Gaurav Sharma ${ }^{2}$
}

${ }^{1}$ Western Ghat Regional Centre, Zoological Survey of India, Kozhikode, Kerala 673006, India

${ }^{2}$ Zoological Survey of India, M-Block, New Alipore, Kolkata, West Bengal 700053, India ${ }^{1}$ kpgiris@gmail.com (corresponding author), ${ }^{2}$ drgaurav.zsi.india@gmail.com

Abstract: Fourteen genera and 33 species of wasps belonging to the family Vespidae are reported from the Indian state of Chhattisgarh, of which seven genera and 23 species are new records for Chhattisgarh.

Keywords: Chhattisgarh, Hymenoptera, new record, taxonomic study, Vespoidea, Vespidae.

Abbreviations: AMNH - American Museum of Natural History, New York, USA; BMNH - Natural History Museum (or British Museum of Natural History), London, UK; HMUG - Hunterian Museum, University of Glasgow, Scotland, UK; MHNG - Muséum d’Histoire Naturelle, Genéve, Switzerland; MCZ - Museum of Comparative Zoology, Harvard University, Cambridge, U.S.A; MP - Muséum national d'Histoire naturelle, Paris, France; MRSN - Museo Regionale di Scienze Naturali, Torino, Italy; MSNG - Museo Civico di Storia Naturale di Genova Giacomo Doria, Genova, Italy; NMNH - National Museum for Natural History, Post bus 9 517, 2300 RA, Leiden, The Netherlands; NZC - National Zoological Collections of Zoological survey of India, Kolkata, India; OLM - Oberösterreichischen Landes museum, Linz, Austria; OUM - Oxford University Museum, Oxford, UK; ZMB - Zoologisches Museum der Humboldt Universität, Berlin, Germany ZMUC - Zoologisk Museum, Københavns Universitet, Denmark; ZMUK-Zoological Museum, University of Kiel, Germany; H - Head; M Mesosoma; NP - National Park; S - Abdominal sterna; T - Abdominal terga; WLS - Wildlife Sanctuary.
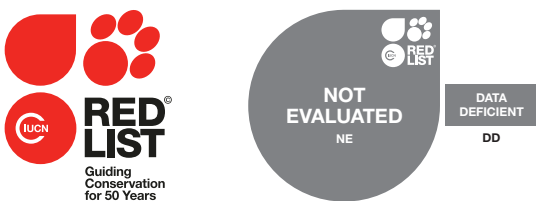

Phimenes flavopictum
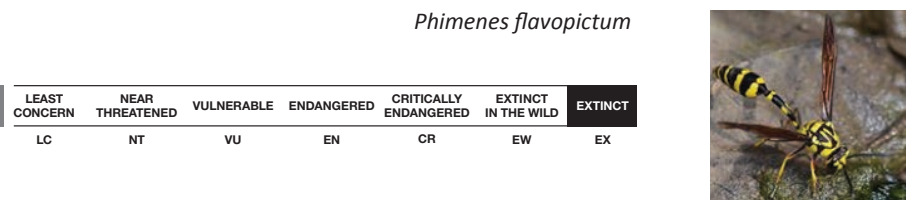

DOI: http://dx.doi.org/10.11609/jott.2426.7.14.8096-8127 | ZooBank: urn:Isid:zoobank.org:pub:20CB265E-7784-4050-82B9-AEB451377732

Editor: Bolívar R. Garcete-Barrett, Universidad Nacional de Asunción, San Lorenzo, Paraguay.

Date of publication: 26 November 2015 (online \& print)

Manuscript details: Ms \# 03823 | Received 21 October 2013 | Final received 08 June 2015 | Finally accepted 28 September 2015

Citation: Kumar, P.G. \& G. Sharma (2015). Taxonomic studies on Vespid Wasps (Hymenoptera: Vespoidea: Vespidae) of Chhattisgarh, India. Journal of Threatened Taxa 7(14): 8096-8127; http://dx.doi.org/10.11609/jott.2426.7.14.8096-8127

Copyright: (C) Kumar \& Sharma 2015. Creative Commons Attribution 4.0 International License. JoTT allows unrestricted use of this article in any medium, reproduction and distribution by providing adequate credit to the authors and the source of publication.

Funding: None.

Conflict of Interest: The authors declare no competing interests.

Author Details: Dr. P. Girish Kumar, is currently working as a Senior Zoological Assistant in ZSI, Western Ghats Regional Centre, Kozhikode, Kerala. His area of research is the biosystematic studies of Hymenoptera with special reference to Scoliidae, Vespidae and Eucharitidae. Dr. Gaurav Sharma is currently working as Scientist-D in ZSI, Kolkata. His area of research is the biosystematics and ecological studies of Odonata, Lepidoptera, Hymenoptera and higher vertebrates.

Author Contribution: Both authors studied the present subject. First author identified and prepared the manuscript. Second author helped to prepare the manuscript.

Acknowledgements: The authors are grateful to Dr. Kailash Chandra, Director-in-Charge and Principal Investigator of CAMPA project, Zoological Survey of India, Kolkata, for providing the specimens for our studies, guidance, facilities and encouragements.

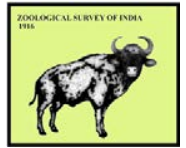




\section{INTRODUCTION}

Vespidae is a cosmopolitan family of Hymenoptera (Insecta), popularly known as wasps. The members of this family are predominantly found in tropical regions of the World, with more than 5000 species occurring worldwide. Adults are usually black or brown, often extensively marked with yellow or white. In solitary species the larva is usually predatory on the caterpillars of other insects, in a cell constructed and mass-provisioned by the adult female. The larva is rarely supplied with a mixture of pollen and nectar instead. In social wasps the larva is progressively fed on masticated insects or rarely predominantly on glandular secretions by adult females. Vespid wasps play important roles in an ecosystem, and thus they can be good bio-indicators for environmental conditions and habitat perturbation. Because of their predaceous habits, they have the potential of being effective biological control agents. Adults are minute to large $(6-28 \mathrm{~mm})$ in size. Solitary wasps nest either in the soil, in pre-existing cavities (such as abandoned mud nest of other hymenopterans or beetle tunnels in wood) or in free mud nests built by themselves. Social wasps often make spectacular paper nests and defend their colony vigorously by stinging.

Bingham (1897) and Das \& Gupta (1989) made valuable contributions on the taxonomy of the Vespidae from India and its adjacent countries. Nevertheless, the vespid fauna from the State of Chhattisgarh is very poorly and fragmentarily known, with only 7 genera and 10 species recorded till date (Dover \& Rao, 1922; Soika, 1981; Das \& Gupta, 1989; Kumar, 2012 a \& b; Kumar \& Kishore, 2012; Kumar et al, 2013; Kumar \& Carpenter, 2013; Kumar \& Sharma, 2013). In this paper, an attempt has been made to provide a consolidated account on the fauna of the family Vespidae from Chhattisgarh, with 14 genera and 33 species recorded, of which 7 genera and 23 species are new records for the state.

\section{MATERIAL AND METHODS}

A systematic account on the vespid fauna of Chhattisgarh is given below, based on the collections from different localities of the state, as well as on the data from the published literature. The new material examined for this study was added to the "National Zoological Collections" of the Zoological Survey of India, Kolkata (NZC).
Systematic Account

Order Hymenoptera

Superfamily Vespoidea

Family Vespidae

Subfamily Polistinae

Tribe Polistini

Genus Polistes Latreille, 1802

Subgenus Polistes (Gyrostoma) Kirby, 1828

1. Polistes (Gyrostoma) olivaceus (De Geer, 1773)

2. Polistes (Gyrostoma) rothneyi krombeini van der Vecht, 1968

3. Polistes (Gyrostoma) wattii Cameron, 1900

Subgenus Polistes (Polistella) Ashmead, 1904

4. Polistes (Polistella) stigma tamula (Fabricius, 1798)

5. Polistes (Polistella) strigosus strigosus Bequaert, 1940

Tribe Ropalidiini

Genus Ropalidia Guérin-Méneville, 1831

6. Ropalidia brevita Das \& Gupta, 1989

7. Ropalidia marginata (Lepeletier, 1836)

8. Ropalidia rufocollaris (Cameron, 1900)

9. Ropalidia stigma (Smith, 1858)

10. Ropalidia jacobsoni (du Buysson, 1908)

11. Ropalidia variegata (Smith, 1852)

12. Ropalidia cyathiformis (Fabricius, 1804)

Subfamily VESPINAE

Genus Vespa Linnaeus, 1758

13. Vespa auraria Smith, 1852

14. Vespa tropica haematodes Bequaert, 1936

\section{Subfamily EUMENINAE}

Genus Allorhynchium van der Vecht, 1963

15. Allorhynchium argentatum (Fabricius, 1804)

16. Allorhynchium metallicum (de Saussure, 1852)

Genus Antepipona de Saussure, 1855

17. Antepipona ceylonica (de Saussure, 1867)

18. Antepipona ovalis (de Saussure, 1853)

19. Antepipona sibilans (Cameron, 1903)

Genus Anterhynchium de Saussure, 1863

20. Anterhynchium abdominale (Illiger, 1802)

20a). Anterhynchium abdominale abdominale (Illiger, 1802)

20b). Anterhynchium abdominale bengalense (de Saussure, 1852)

21. Anterhynchium mellyi (de Saussure, 1852)

Genus Antodynerus de Saussure, 1855

22. Antodynerus flavescens flavescens (Fabricius, 1775)

Genus Delta de Saussure, 1855

23. Delta conoideum (Gmelin, 1790)

24. Delta dimidiatipenne (de Saussure, 1852)

25. Delta esuriens (Fabricius, 1787)

26. Delta pyriforme pyriforme (Fabricius, 1775) 
Genus Indodynerus Gusenleitner, 2008

27. Indodynerus capitatus Gusenleitner, 2008

Genus Oreumenoides Giordani Soika, 1961

28. Oreumenoides edwardsii (de Saussure, 1852)

Genus Pareumenes de Saussure, 1855

29. Pareumenes brevirostratus (de Saussure, 1855)

Genus Phimenes Giordani Soika, 1992

30. Phimenes flavopictum (Blanchard, 1840)

Genus Rhynchium Spinola, 1806

31. Rhynchium brunneum brunneum (Fabricius, 1793)

32. Rhynchium carnaticum (Fabricius, 1798)

Genus Xenorhynchium van der Vecht, 1963

33. Xenorhynchium nitidulum (Fabricius, 1798)

\section{Family Vespidae}

The family Vespidae is recognised by the following characters: Antennae 13 segmented in male and 12 segmented in female; inner margin of eyes deeply emarginate; dorsal rim of torulus simple; pronotum extending back to tegula; mesopleuron without any oblique suture; wings longitudinally folded in repose (except in Masarinae and Stenogastrinae); fore wing with first discoidal cell elongate and longer than submedian cell (except in Masarinae); hind wing with an anal cell and enclosed cells, without distinct claval lobe; mesocoxae and metacoxae contiguous; trochanters not divided and trochantellus generally absent; middle tibiae with one or two apical spurs; tarsal claws toothed, bifid or simple; gaster with spiracles on 1-7 segments and a sting without sheaths; male genitalia with characteristic spiniform parameres; both sexes macropterous.

The family Vespidae is represented by six subfamilies. Of these, two subfamilies, viz., Euparagiinae and Masarinae do not occur in India. Out of other four subfamilies, one subfamily, viz., Stenogastrinae has not been reported from Chhattisgarh till date. Of course, only three subfamilies, viz., Polistinae, Vespinae and Eumeninae are reported from the state of Chhattisgarh.

\section{Subfamily Polistinae}

The members of the subfamily Polistinae are commonly known as paper wasps. This subfamily is divided into two tribes, viz., Polistini and Ropalidiini. They are known to occur in India including Chhattisgarh. A key to distinguish Polistini and Ropalidiini is provided.

\section{Tribe Polistini}

The tribe Polistini is represented by a single genus, Polistes Latreille from the Indian subcontinent.

Key to the subfamilies of the Vespidae occurring in Chhattisgarh (Modified from Carpenter \& Nguyen 2003)

1. Parategula on mesoscutum usually present; tarsal claws usually bifid; posterior lingual plate longer than broad; solitary or

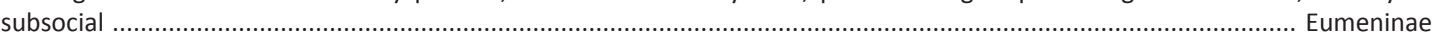
Parategula absent; tarsal claws simple; posterior lingual plate as broad as long; eusocial ................................................ 2 Hind coxa with dorsal carina on posterior surface; hind wing without jugal lobe; metasoma sessile with T1 having abrupt declivity,

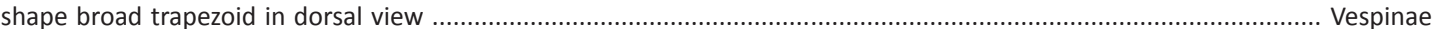
Hind coxa without dorsal carina; hind wing with jugal lobe; metasoma variable in shape, petiolate to subsessile or funnel shaped in dorsal view Polistinae

Key to the tribes of Polistinae occurring in Chhattisgarh

1. First gastral segment always petiolate and usually strongly swollen apically (Image 6-12); pronotal lobe apically in front of tegula without a carina; dorsal episternal groove always absent; subtegular area basally in front of pronotal lobe not margined with a

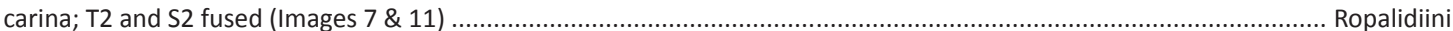
First gastral segment subpetiolate, shorter than second segment (Images 1-5); pronotal lobe apically in front of tegula with a distinct carina; dorsal episternal groove either present or absent; subtegular area basally in front of pronotal lobe margined with distinct carina; T2 and S2 never fused. (Muscle slit of propodeum long and narrow; subdiscoidous joins postnervulus at or close to middle; apical margin of metanotum usually almost truncate) ........................................................................... Polistini

Key to the subgenera of Polistes occurring in Chhattisgarh

1. Pronotal fovea present; clypeus not extending far beyond the anterior tentorial pits (Fig. 2); anal lobe of hind wing large and separated from the rest of the wing membrane by a smooth incision ............................................ Polistes (Gyrostoma) Kirby Pronotal fovea absent; clypeus extending far beyond the anterior tentorial pits (Fig. 6); anal lobe of hind wing more or less reduced ................................................................................................................................ Polistes (Polistella) Ashmead 


\section{Genus Polistes Latreille, 1802}

Polistes Latreille, 1802: 363.

Type species: Vespa gallica Linnaeus, 1767.

Three subgenera, viz., P. (Polistes) Latreille, 1802, P. (Gyrostoma) Kirby, 1828, P. (Polistella) Ashmead, 1904 are recorded from the Indian subcontinent. In Chhattisgarh, only two subgenera have been recorded. A key for these genera has been provided.

\section{Subgenus Polistes (Gyrostoma) Kirby}

Gyrostoma Kirby, in Kirby \& Spence, 1828: 36, 361.

Type species: Cyclostoma gigas Kirby \& Spence, 1826.

Gyrostoma; Carpenter, 1996: 4, syns.

The subgenus Polistes (Gyrostoma) Kirby is represented by 21 species and an additional 30 subspecies from the world. Of these, only five species and an additional four subspecies have been reported from India (Carpenter 1996). Here the state Chhattisgarh represents only three species. A key for ready reference has been provided here.

\section{Polistes (Gyrostoma) olivaceus (De Geer, 1773)} (Image 1)

Vespa olivacea De Geer, 1773: 582.

Type: Sex not mentioned, America (NHRM).

Polistes (Gyrostoma) olivaceus; Carpenter, 1996: 5.

Material examined: 15139/H3, 1 female, 14.v.2013, Pingla Nala, Tamor Pingla WLS, Balrampur District, Chhattisgarh, India, coll. A. Raha \& party.

Diagnosis: Female: Clypeus densely finely punctate, with a few larger scattered punctures interposed; frons, vertex and temple with fine scattered punctures; occipital carina incomplete; pronotum sparsely finely punctate; mesoscutum almost impunctate; scutellum, metanotum and metapleuron impunctate; mesopleuron behind epicnemial carina and above sterno-pleural suture with scattered fine punctures; propodeum with distinct striations without distinct lateral edge; gaster almost impunctate, covered with short velvety pubescence; S1 transversely striated.

Colour description: Body yellow with black markings and a few reddish markings. Black markings as follows: basal and apical margin of clypeus narrowly, mandibular teeth, a short line on the raised part of interantennal space, a mark above each antennal socket, a band on vertex, occiput, a line on scape and flagellum above, in front of pronotal carina, a mark on pronotum ventrally towards propleuron, mesoscutum (except a longer median and two shorter lateral yellow lines), almost all the thoracic sutures, a line along the median groove of propodeum, T1 narrowly at base, T2-T5 and S2-S5 with bisinuate marks, a line below coxae, another line on hind tibiae above. The reddish markings as follows: pronotum partly dorsally, two curved lines on propodeum on sides, $\mathrm{T} 2$ at base and legs partly.

Size $(\mathrm{H}+\mathrm{M}+\mathrm{T} 1+\mathrm{T} 2): 13.5 \mathrm{~mm}$.

Distribution: India: Andhra Pradesh, Arunachal Pradesh, Assam, Chhattisgarh (new record), Gujarat, Himachal Pradesh, Jammu \& Kashmir, Jharkhand, Karnataka, Madhya Pradesh, Manipur, Meghalaya, Nagaland, Odisha, Rajasthan, Sikkim, Tripura, Uttarakhand, Uttar Pradesh, West Bengal. Elsewhere: Afghanistan, Amirantes, Australia, Bangladesh, Cambodia, Chagos Archipelago, Chile (introduced), China, Egypt, Fiji, Indonesia, Iran, Japan, Laos, Madagascar, Malaysia, Marianas, Marquesas, Mauritius, Myanmar, Nepal, New Caledonia, New Zealand, Oman, Pakistan, Philippines, Réunion, Samoa, Seychelles, Singapore, Society Is., Sri Lanka, Tanzania, Thailand, Tongas, Tuamotu Archipelago, U.S.A., Vietnam.

\section{Polistes (Gyrostoma) rothneyi Cameron}

Seventeen subspecies are reported under the species Polistes (Gyrostoma) rothneyi Cameron from the World (Carpenter, 1996). Of these, five subspecies viz., rothneyi rothneyi Cameron, 1900, rothneyi carletoni van der Vecht, 1968, rothneyi krombeini van der Vecht, 1968, rothneyi sikkimensis van der Vecht, 1968, rothneyi vechti Das \& Gupta, 1989 have been reported from India (Das \& Gupta, 1989). Here the state Chhattisgarh represents

Key to the species of Polistes (Gyrostoma) occurring in Chhattisgarh

1. Transverse striations of propodeum strong, almost reach the lower margin of side (Fig. 3); ventral metapleuron with distinct punctures. In males, apophyses longer than wide with some pubescence; tip of last antennal article spatulate in male ........ rothneyi Cameron Transverse striations of propodeum weak, not distinct near lower margin of side (Fig. 1); ventral metapleuron nearly impunctate or with scattered fine punctures; tip of last antennal article pointed, not spatulate in male ........................................................ 2 2. Occipital carina in female incomplete; in males, apophyses flattened and spatulate at apex, shiny and devoid of pubescence .........

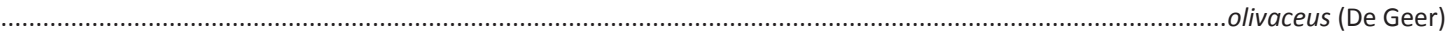
Occipital carina in female complete; in males, apophyses long, narrow and densely pubescent (Fig. 4) .................. wattii Cameron 


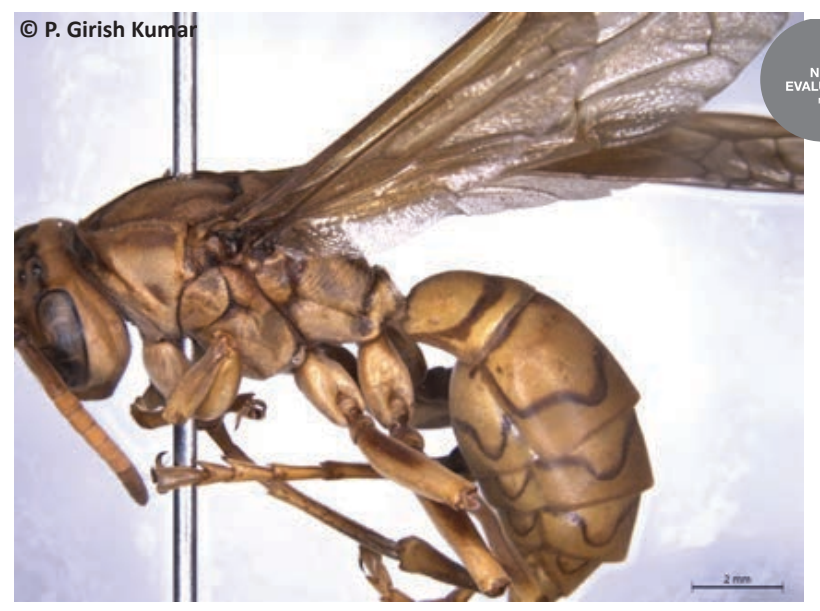

Image 1. Polistes (Gyrostoma) olivaceus (De Geer) Female.

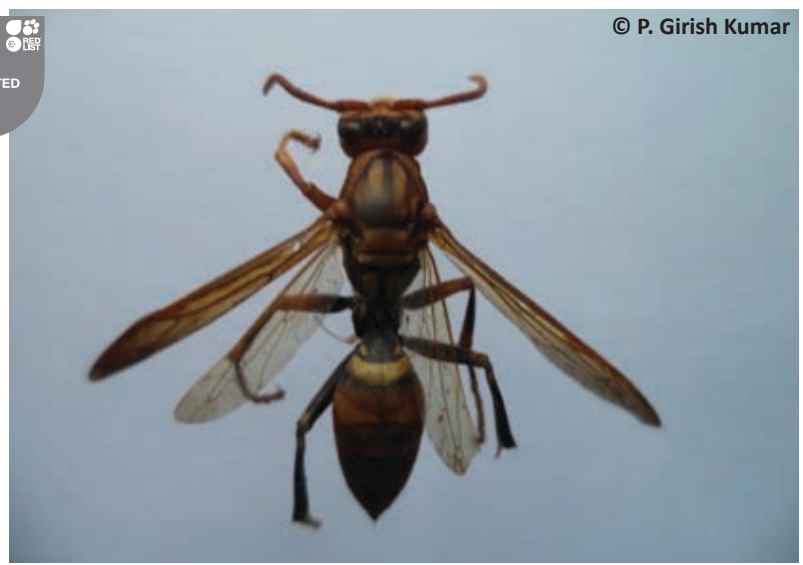

Image 2. Polistes (Gyrostoma) rothneyi krombeini van der Vecht Female. only one subspecies namely rothneyi krombeini van der Vecht, 1968.

\section{Polistes (Gyrostoma) rothneyi krombeini van der Vecht, 1968 (Image 2)}

Polistes (Megapolistes) rothneyi krombeini Vecht, 1968: 100. Type: Female, Tamil Nadu: Coimbatore (AMNH).

Polistes (Gyrostoma) rothneyi krombeini; Carpenter, 1996: 7.

Material examined: 14455/H3, 1 female, 26.viii.2011, Chilpi, Boramdeo WLS, Kabirdham District, Chhattisgarh, India, coll. S.K. Gupta \& party.

Diagnosis: Female: Ventral metapleuron with distinct punctures; transverse striations of propodeum strong, almost reach the lower margin of side; apex of last antennal article spatulate in male; apophyses longer than wide in males.

Colour description: Body predominantly yellow with distinct black and faint reddish-brown colourations. Black portions are as follows: a band on vertex enclosing the ocelli, occiput except at posterior margins, anterior margin of pronotum, mesoscutum except four broad yellow lines, all thoracic sutures broadly, more extended marks on mesopleuron, base and apex broadly and narrow lines separating the larger yellow marks on propodeum, small marks on coxa, trochanter and base of femur of all legs, more extended on hind femur, basal half of mid tibia and mid basitarsus, a broad line on hind tibia above, basal two thirds of hind metatarsus, mark on T1 at basal half, T2-T4 tergites broadly at base, S1 entirely, S2 and S3 basally, a narrow bisinuate line on T2T5 and sternites. Reddish-brown portions are as follows: a band next to basal black band on T2 and T3.
Size $(\mathrm{H}+\mathrm{M}+\mathrm{T} 1+\mathrm{T} 2)$ : $16 \mathrm{~mm}$.

Distribution: India: Chhattisgarh (new record), Karnataka, Kerala, Meghalaya, Tamil Nadu, Uttarakhand.

\section{Polistes (Gyrostoma) wattii Cameron, 1900 (Image 3)}

Polistes wattii Cameron, 1900: 416. Type: Female, West Bengal (BMNH).

Polistes (Gyrostoma) wattii; Carpenter, 1996: 9.

Material examined: 14456/H3, 1 female, 16.viii.2011, Bar village, Barnawapara WLS, Raipur District, Chhattisgarh, India, coll. S.K. Gupta \& party; 14457/H3, 1 female, 27.viii.2011, Fan Riverside, Kabirdham District, Chhattisgarh, India, coll. S.K. Gupta \& party; 15140/H3, 1 female, 26.vii.2012, Bhimbhori Nala, Barnawapara WLS, Raipur District, Chhattisgarh, India, coll. S.K. Gupta \& party; 15141/H3, 1 male, 14.v.2013, Pingla Nala, Tamor Pingla WLS, Balrampur District, Chhattisgarh, India, coll. A. Raha \& party.

Diagnosis: Female: Occipital carina complete; dorsal and ventral metapleuron impunctate; striations on propodeum weak, not distinct near the lower margin of side.

Colour description: Almost uniform yellow colour; hind tibia above usually black; a narrow transverse reddish-brown line on T1 after middle, T2-T5 and S2-S5 with bisinuate reddish-brown line.

Size $(\mathrm{H}+\mathrm{M}+\mathrm{T} 1+\mathrm{T} 2): 13 \mathrm{~mm}$.

Male: Similar to female except clypeus not touching the eye; proximal tooth shorter and broader than other teeth; temple wider; apophyses of subgenital plate long and narrow, not flattened at apex, densely pubescent.

Size $(\mathrm{H}+\mathrm{M}+\mathrm{T} 1+\mathrm{T} 2):$ 10-11 $\mathrm{mm}$.

Distribution: India: Bihar, Chhattisgarh (new record), Delhi, Gujarat, Haryana, Himachal Pradesh, Jammu 
\& Kashmir, Jharkhand, Madhya Pradesh, Meghalaya, Odisha, Punjab, Rajasthan, Uttarakhand, Uttar Pradesh, West Bengal. Elsewhere: Afghanistan, China, Iran, Iraq, Mauritius, Oman, Pakistan, Saudi Arabia, U.A.E.

\section{Subgenus Polistes (Polistella) Ashmead}

Polistes (Polistella) Ashmead, 1904: 133.

Type species: Polistes manillensis Saussure, 1853.

There are presently 19 species of this genus. Das and Gupta (1989) recorded 15 species along with five subspecies and Gusenleitener (2006) described four species. Only two species of this genus occur in Chhattisgarh.

\section{Polistes (Polistella) stigma tamulus (Fabricius, 1798) (Image 4)}

Vespa tamula Fabricius, 1798: 263. Type Female, "in India Orientali, Dom Daldorff" (ZMUK).

Polistes (Polistella) stigma tamulus; Carpenter, 1996: 16.

Material examined: 14458/H3 \& 14459/H3, 2 female, 18.vii.2011, Barnawapara Camp, Barnawapara WLS, Raipur District, Chhattisgarh, India, coll. S.K. Gupta \& party; 14460/H3, 1 female, 6.x.2011, Aamagaon forest, Barnawapara WLS, Raipur District, Chhattisgarh, India, coll. S.K. Gupta \& party; 14461/H3, 1 female, 7.xi.2011, Parbatiya Nala, Barnawapara WLS, Raipur District, Chhattisgarh, India, coll. A.K. Sarsavan \& party; 14461/H3, 1 female, 7.xi.2011, Parbatiya Nala, Barnawapara WLS, Raipur District, Chhattisgarh, India, coll. A.K. Sarsavan \& party; 14462/H3, 1 female, 19.viii.2011, Anda village, Durg District, Chhattisgarh, India, coll. S.K. Gupta \& party; 14463/H3, 1 female, 18.x.2011, Kodhmali, Gariaband District, Chhattisgarh, India, coll. S.K. Gupta \& party; 14464/H3 \& 14465/H3, 2 female, 17.xi.2011, Pipartala forest, Kabirdham District, Chhattisgarh, India, coll. S.K. Gupta \& party; 14466/H3, 1 female, 25.v.2012, Bardand, Badalkhol, Jashpur District, Chhattisgarh, India, coll. A. Raha \& party; 14467/H3, 1 male, 27.v.2012, Pakhridhab, Badalkhol, Jashpur District, Chhattisgarh, India, coll. A. Raha \& party; 14468/H3, 1 female, 27.v.2012, Degadegi Nala, Badalkhol, Jashpur District, Chhattisgarh, India, coll. A. Raha \& party; 14469/ H3, 1 female, 3.vi.2012, Devpahri, Lemru, Korba District, Chhattisgarh, India, coll. Kailash Chandra \& party; 15143/ H3, 1 female, 4.vii.2011, Karidongri, Barnawapara WLS, Raipur District, Chhattisgarh, India, coll. Kailash Chandra \& party; 15144/H3, 1 male, 15.xi.2011, Kudai Nala forest, Boramdeo WLS, Kabirdham District, Chhattisgarh, India, coll. S.K. Gupta \& party; 15145/H3, 1 female, 4.xii.2011, Rengakhar forest, Boramdeo WLS, Kabirdham District, Chhattisgarh, India, coll. S.K. Gupta \& party; 15146/H3, 1 female, 9.x.2012, Bhothali, Sitanadi WLS, Dhamtari District, Chhattisgarh, India, coll. S.K. Gupta \& party.

Diagnosis: Female: S1 without distinct margin at base; T1 about as long as wide; median groove of propodeum shallow, with close fine transverse striations; forewing with subapical fuscous cloud.

Colour description: Body predominantly reddish with some black markings and the following yellow markings: clypeus, mandible, a broad line along inner orbit up to lower half of ocular sinus, a line on temple bordering eye margin, malar space, basal and apical margin of pronotum narrowly, a line on scutellum at base, another on metanotum at base, a mark on subtegular area, an elongated mark on mesepisternum at top and another in the middle of apico-lateral margin in front of metapleuron, raised ventral margin of mesepisternum and ventral metapleuron each, a mark on dorsal metapleuron, two lines on mesosternum,
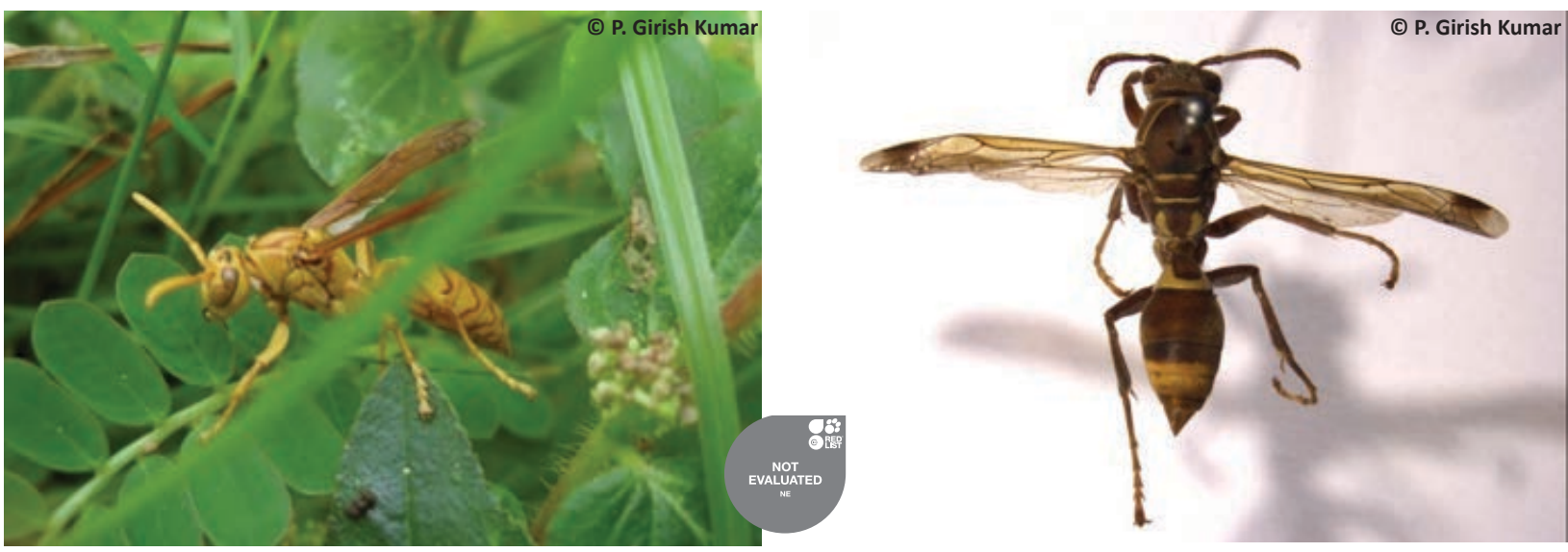

Image 3. Polistes (Gyrostoma) wattii Cameron Female.

Image 4. Polistes (Polistella) stigma tamula (Fabricius) Female. 
1. Forewing with subapical fuscous cloud (Fig. 5); median groove of propodeum shallow with close fine transverse striations; S1 without distinct margin at base; head and mesosoma light reddish brown with predominant yellow markings (Image 4); T1 with yellow mark (Image 4); T2 without yellow (Image 4) ......................... stigma tamulus (Fabricius, 1798) Forewing without subapical fuscous cloud (Fig. 7); median groove of propodeum deep with strong transverse striations; S1 with distinct margin at base; head and mesosoma red without yellow markings (Image 5); T1 without yellow mark (Image 5); T2 almost completely yellow (Image 5) ............................ strigosus strigosus Bequaert, 1940

two broad curved marks on propodeum, apical valvula entirely, fore coxa in front entirely, marks on mid coxa in front and two lines on hind coxa below, T1 except broad reddish mark at base, apical broad band on T3 and S3, fourth gastral segment almost entirely, S1 and a narrow band on T2 apically.

Size $(\mathrm{H}+\mathrm{M}+\mathrm{T} 1+\mathrm{T} 2)$ : 10-11 mm.

Male: Size $(H+M+T 1+T 2): 11 \mathrm{~mm}$. Similar to the female except with a black mark on frons and vertex.

Distribution: India: Bihar, Chhattisgarh (new record), Delhi, Himachal Pradesh, Jharkhand, Karnataka, Kerala, Maharashtra, Meghalaya, Odisha, Pondicherry, Sikkim, Tamil Nadu, Uttarakhand, Uttar Pradesh, West Bengal. Elsewhere: Sri Lanka.

\section{Polistes (Polistella) strigosus strigosus Bequaert, 1940 (Image 5)}

Polistes strigosus Bequaert, 1940: 269-272.

Holotype Female, China: Wong-Sa-Shui (MCZ).

Polistes (Polistella) strigosus strigosus; Das \& Gupta, 1983: 415

Material examined: 15142/H3, 1 female, 10.v.2012, Mari Nala, Guru Ghasidas NP, Koriya District, Chhattisgarh, India, coll. S.K. Gupta \& party.

Diagnosis: Female: Pronotum ribbed; head narrower than mesosoma; forewing without subapical fuscous cloud; median groove of propodeum deep, with strong transverse striations; S1 with distinct margin at base.

Colour description: Body almost entirely and uniformly ferruginous, with ocellar region, flagellum above and some sutures of head and mesosoma black; T2 almost entirely yellow; wings yellowish, paler apically.

Size $(\mathrm{H}+\mathrm{M}+\mathrm{T} 1+\mathrm{T} 2): 14.5 \mathrm{~mm}$

Distribution: India (new record): Chhattisgarh (new record). Elsewhere: China, Taiwan.

\section{Tribe Ropalidiini}

Kojima \& Carpenter (1997) reported four genera, viz., Belanogaster de Saussure, 1854, Parapolybia de Saussure, 1853, Polybioides du Buysson, 1913 and Ropalidia Guérin-Méneville, 1831 from the world, which are also reported from India. The state Chhattisgarh is represented by only one genera, namely, Ropalidia.

\section{Genus Ropalidia Guérin-Méneville, 1831}

Ropalidia Guérin-Méneville, 1831: pl. 9, fig. 8. Type species: Ropalidia maculiventris Guérin-Méneville, 1831. Around 180 Ropalidia species currently recognised worldwide of which 26 species have been recorded from the Indian subregion (Kojima et al., 2007). Of these, seven species under this genus have been reported from the state of Chhattisgarh (key provided).

\section{Ropalidia brevita Das \& Gupta, 1989 (Image 6)}

Ropalidia (Anthreneida) brevita Das \& Gupta, 1989:

121. Holotype Male, Delhi: University ridge (NZC).

Ropalidia brevita; Kojima et al. 2007: 380.

Material examined: 14470/H3 \& 14471/H3, 2 female, 11.vii.2011, Nawapara, Raipur District, Chhattisgarh, India, coll. S.K. Gupta \& party; 14472/H3, 1 male, 22.vii.2011, Barvillage, Barnawapara WLS, Raipur District, Chhattisgarh, India, coll. S.K. Gupta \& party; 14473/H3, 1 female, 24.vii.2011, Turturiya forest, Raipur District, Chhattisgarh, India, coll. S.K. Gupta \& party; 14474/ H3, 1 female, 16.viii.2011, Bar village, Barnawapara WLS, Raipur District, Chhattisgarh, India, coll. S.K. Gupta \& party;14475/H3, 1 female, 5.x.2011, Bar village, Barnawapara WLS, Raipur District, Chhattisgarh, India, coll. S.K. Gupta \& party; 14476/H3, 1 female, 17.viii.2011, Khadgaon, Surguja District, Chhattisgarh, India, coll. A. Raha \& party; 14477/H3, 1 female, 27.v.2012, Pakhridhab, Badalkhol, Jashpur District, Chhattisgarh, India, coll. A. Raha \& party; $14478 /$ H3 to $14881 /$ H3, 3 female \& 1 male, 10-14.i.2013, Kirandul, Dandewada District, Chhattisgarh, India, coll. P. Girish Kumar; 15147/ H3, 1 female, 4.x.2011, Debakhar village, Barnawapara WLS, Raipur District, Chhattisgarh, India, coll. S.K. Gupta \& party; 15148/H3, 1 female, 4.x.2011, Chirmiri, Koriya District, Chhattisgarh, India, coll. Mandal \& party; 15149/H3 \& 15150/H3, 2 male, 9.xi.2011, Dhuria, Karan Chala, Surguja District, Chhattisgarh, India, coll. A. Raha \& party;15151/H3, 1 female, 7.xii.2011, Dond 
Nala, Barnawapara WLS, Raipur District, Chhattisgarh, India, coll. S.K. Gupta \& party; 15152/H3, 1 female, 10.v.2012, Mari Nala, Guru Ghasidas NP, Koriya District, Chhattisgarh, India, coll. S.K. Gupta \& party; 15153/H3 \& 15154/H3, 2 female, 12.v.2012, Subudu Nala, Guru Ghasidas NP, Koriya District, Chhattisgarh, India, coll. S.K. Gupta \& party; 15155/H3, 1 female, 17.v.2012, Beliya, Koriya District, Chhattisgarh, India, coll. S.K. Gupta \& party; $15156 / \mathrm{H} 3$ to $15165 / \mathrm{H} 3,10$ female, 21.v.2012, Lakshman Jhiria, Guru Ghasidas NP, Koriya District, Chhattisgarh, India, coll. S.K. Gupta \& party; 15166/ H3 to 15170/H3, 5 female, 13.vi.2012, Sihawal Sagar, Achanakmar WLS, Bilaspur District, Chhattisgarh, India, coll. A. Raha \& party; 15171/H3, 1 female, 25.ix.2012, Balod, Durg District, Chhattisgarh, India, coll. A. Raha \& party; 15172/H3, 1 female, 11.v.2013, Jalpani, Guru Ghasidas NP, Koriya District, Chhattisgarh, India, coll. A. Raha \& party; $151723 / \mathrm{H} 3$ to $15177 / \mathrm{H} 3,5$ female, 14.v.2013, Pingla Nala, Tamor Pingla WLS, Balrampur District, Chhattisgarh, India, coll. A. Raha \& party.

Diagnosis: Female: T1 proportionally wider with its maximum width in dorsal view nearly half as wide as that of T2; propodeum with paired, longitudinal basal carinae, with weak transverse striation and scattered shallow punctures between basal carinae; striations lateral to carinae weak; propodeal orifice very narrow.

Colour description: Body red with the following yellow portions: antennal scape below, a band on clypeus at apex, mandible (except at tip), inner orbit below ocular sinus (sometimes faint), pronotum anteriorly, two marks on postscutellum (sometimes fused), two enlarged marks on apical half of propodeum, a faint mark on sides of mesosternum, fore and middle coxae in front, a line on lateral side of hind coxa, tarsal segments of all legs (highly variable), a narrow apical band on T1 and a broad apical band on T2. In some portions black patches are mixed with reddish body. The extents of yellow and black markings are variable.

Size $(\mathrm{H}+\mathrm{M}+\mathrm{T} 1+\mathrm{T} 2): 12 \mathrm{~mm}$.

Male: Similar to female in size and general appearance. Clypeus, supraclypeal area, inter antennal space, inner orbit below ocular sinus are completely yellow. Male terminal antennal flagellomeres less strongly curved and bluntly pointed at apex, approximately twofold as long as its basal width; aedeagus not spatulate apically.

Distribution: India: Assam, Chhattisgarh (new record), Delhi, Goa, Haryana, Himachal Pradesh, Karnataka, Kerala, Odisha, Rajasthan, Sikkim, Uttarakhand, Uttar Pradesh, West Bengal.

\section{Ropalidia marginata (Lepeletier, 1836) (Image 7)}

Epipona marginata Lepeletier, 1836: 541. Type, "Inde" (?MRSN).

Ropalidia marginata; Kojima et al. 2007: 380.

Material examined: 14482/H3, 1 female, 23.iv.1975, Mahasamund, Mahasamund District, Chhattisgarh,

\section{Key to the species of Ropalidia occurring in Chhattisgarh}

1. Propodeum at base with a pair of carina (Fig. 8); propodeal orifice very narrow (Fig. 8) ..................................... 2 Propodeum without such carina (Fig. 11); propodeal orifice wider, more or less rounded dorsally (Fig. 11) ............... 3

2. T2 with a broad apical yellow band, with its width near the middle more than one-fourth length of the tergum (Image 6); clypeus wider than long in male ............................................................................................... brevita Das \& Gupta T2 with or without a narrow apical yellow band, with its width approximately or less than one-fifth length of the tergum (Image 7); clypeus about as wide as long in male ...................................................................... marginata (Lepeletier)

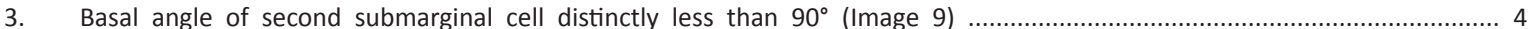
Basal angle of second submarginal cell larger than $90^{\circ}$ (Images $10,11 \& 12$ ) .............................................................. 5

4emale antenna slender; first flagellomere (Fig. 9) more than $3 x$ as long as its maximum width; second flagellomere (Fig. 9) longer than wide; terminal flagellomere distinctly longer than its maximum width; T1 more than 2.6x as long as wide; ventral metapleuron with punctures ..................................................................................... rufocollaris (Cameron) Female antenna thicker; first flagellomere nearly $3 x$ as long as its maximum width; second as long as wide; terminal slightly longer than its maximum width; first metasomal segment less than $2.4 \mathrm{x}$ as long as wide; ventral metapleuron smooth without punctures .......................................................................................................................stigma (Smith)

5. Propodeal valvula small, in lateral view barely covering propodeal teeth forming propodeal orifice; first metasomal segment short, in lateral view with dorsal margin arising from posterior margin of basal slit for reception of metasomal suspensory ligament (Fig. 13); second segment in lateral view vertically cut off posteriorly (Fig. 13); male flagellum with developed tyloids, more or less serrated ventrally; terminal article of male weakly curved ............................ cyathiformis (Fabricius) Propodeal valvula large, semicircular or broadly rounded triangle in outline, in lateral view covering most part of the propodeal teeth forming the propodeal orifice; other characters partly or completely different................ 5 Median line of median groove of propodeum not distinct, groove wider in the middle; temple as wide as eye in profile; T1 in lateral view with dorsal margin more or less evenly convex, highest at level of posterior margin of sternum (Fig. 12) ....... margin more strongly convex in posterior half, highest slightly posterior to level of posterior margin of sternum (Fig. 10)................ 


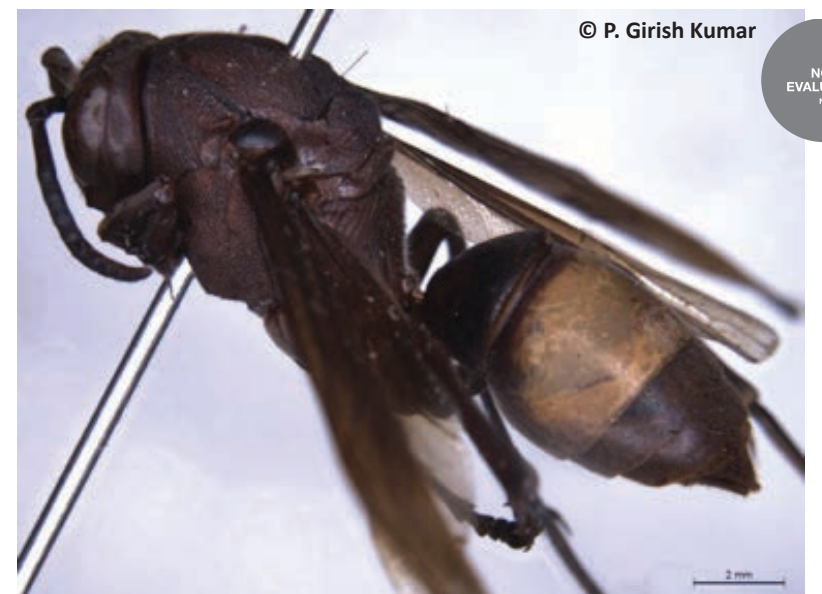

Image 5. Polistes (Polistella) strigosus strigosus Bequaert Female.

India, coll. S.K. Gupta \& party; 14483/H3 \& 14484/H3, 2 female, 24.iv.1975, Raipur Library, Raipur District, Chhattisgarh, India, coll. S.K. Gupta \& party.

Diagnosis: Female: Head wider than mesosoma in front of tegulae; propodeum with paired, longitudinal basal carinae, with weak transverse striation and scattered shallow punctures between basal carinae; striation lateral to carinae weak; propodeal orifice very narrow; forewing with three cubital cells; epicnemium smooth.

Colour description: Body reddish-brown. The following parts with yellow markings: Mandible with a large mark, apical margin of clypeus broadly, a broad band along inner orbit up to ocular sinus, a line on ventral side of scape, a narrow line on basal margin of pronotum, two large marks on scutellum and postscutellum, two marks on mesopleuron, two elongated marks on apical half of propodeum, fore coxa entirely in front, middle and hind coxa with lines (sometimes absent), T1 and T2 with apical narrow fascia. Wings yellowish hyaline, apical half of radial cell dark brown, stigma yellow.

Size $(\mathrm{H}+\mathrm{M}+\mathrm{T} 1+\mathrm{T} 2)$ : 11-12 $\mathrm{mm}$.

Distribution: Andhra Pradesh, Chhattisgarh (new record), Gujarat, Karnataka, Kerala, Madhya Pradesh, Maharashtra, Odisha, Punjab, Rajasthan, Tamil Nadu, Uttarakhand, Uttar Pradesh, West Bengal. Elsewhere: Sri Lanka, Pakistan, Myanmar, Vietnam, Malaysia, Indonesia, Philippines, New Guinea, New Britain, Australia.

\section{Ropalidia rufocollaris (Cameron, 1900) (Image 8)}

Icaria rufocollaris Cameron, 1900: 497. Holotype Female, India: Meghalaya: Khasi Hills (BMNH).

Ropalidia rufocollaris; Kojima et al., 2007: 383.

Material examined: 15260/H3, 1 female, 14.i.2013, Kirandul, Dandewada District, Chhattisgarh, India, coll. P.

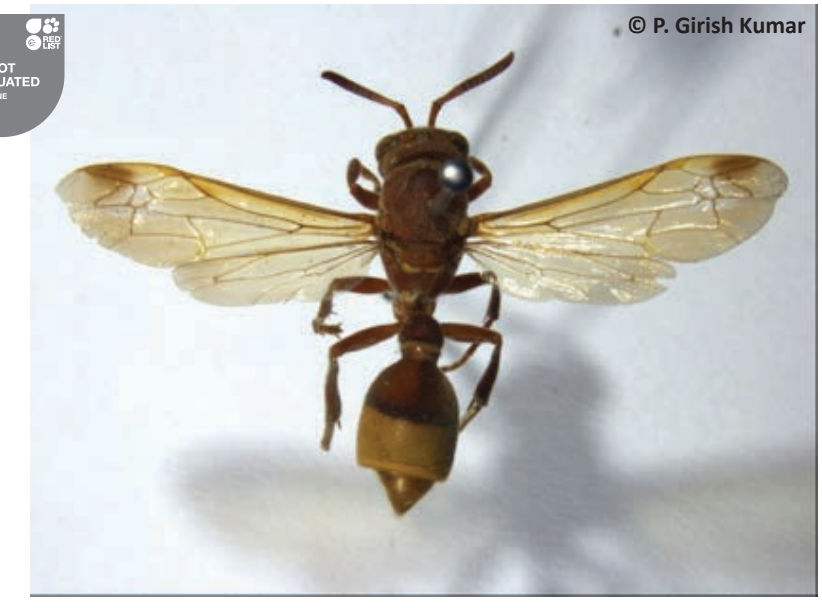

Image 6. Ropalidia brevita Das \& Gupta Female.

Girish Kumar.

Diagnosis: Female: Antenna slender; first flagellomere more than three times as long as its apical width; second flagellomere longer than wide; apical flagellomere distinctly longer than its basal width; posterior face of propodeum finely, transversely striate; propodeum without paired, longitudinal, basal carinae; basal angle of second submarginal cell distinctly less than $90^{\circ}$; suture between $\mathrm{T} 2$ and S2 distinct throughout the segment; clypeus with a yellow triangular spot at apex; $\$ 2$ wholly black.

Colour description: Head reddish. A triangular mark at the apical margin of clypeus, and a large mark on mandible at base, yellow. Faint yellow marks interantennal space and at inner eye margin opposite to antennal toruli. A mark on frons including ocelli, black. Antennal flagellum slightly blackish above. Mesosoma and metasoma black. Pronotum, mesopleuron and gastral petiole (except a basal black mark and a lateral yellow line), red. Pronotal carina, scutellum, a curved line on metanotum at base, a spot on mesopleuron, marks on propodeum, marks on all coxae, a line on gastral petiole laterally at base up to half of the segment, T2 narrowly at base and apex, and a characteristic spot at base, yellow. Legs reddish with blackish tinge.

Size $(\mathrm{H}+\mathrm{M}+\mathrm{T} 1+\mathrm{T} 2): 11 \mathrm{~mm}$.

Distribution: India: Assam, Chhattisgarh (new record), Kerala, Meghalaya, Sikkim, Tamil Nadu, Tripura, Uttarakhand, West Bengal. Elsewhere: Laos, Myanmar, Thailand, Tibet, Vietnam.

\section{Ropalidia stigma (Smith, 1858) (Image 9)}

Polybia stigma Smith, 1858: 114. Type: Male, Malaysia: Sarawak (OUM).

Ropalidia stigma; Kojima et al. 2007: 384. 


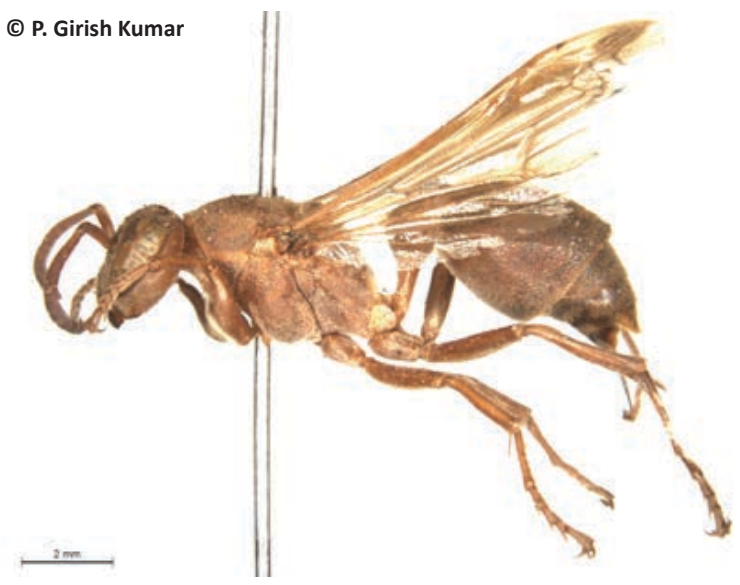

Image 7. Ropalidia marginata (Lepeletier) Female.

Material examined: 14485/H3, 1 female, 22.iv.1975, Dhamtari, Dhamtari District, Chhattisgarh, India, coll. S.K. Gupta \& party; 14486/H3 \& 14487/H3, 2 female, 12.i.2013, Kirandul, Dandewada District, Chhattisgarh, India, coll. P. Girish Kumar; 15178/H3, 1 female, 28.iii.2012, Jhiragaon, Jagadalpur, Bastar District, Chhattisgarh, India, coll. R.P. Gupta \& party; 15179/ H3, 1 female, 12.v.2012, Subudu Nala, Guru Ghasidas NP, Koriya District, Chhattisgarh, India, coll. S.K. Gupta \& party; 15180/H3 \& 15181/H3, 2 female, 7.vi.2012, Rengakhar forest, Boramdeo WLS, Kabirdham District, Chhattisgarh, India, coll. Kailash Chandra \& party; 15182/H3, 1 female, 8.vi.2012, Khara, Kawardha District, Chhattisgarh, India, coll. A. Raha \& party; $15183 / \mathrm{H} 3$ to 15251/H3, 70 female, 9.vi.2012, Chilpi,Boramdeo WLS, Kabirdham District, Chhattisgarh, India, coll. A. Raha \& party; $15252 / \mathrm{H} 3$ to $15259 / \mathrm{H} 3,8$ female, 31.iii.2014, Chilpi,Boramdeo WLS, Kabirdham District, Chhattisgarh, India, coll. E.E. Jehamalar \& party.

Diagnosis: Female: Ventral metapleuron smooth without punctures; antenna thicker; first flagellomere nearly threefold as long as its apical width; second as long as wide; terminal slightly longer than its basal width.

Colour description: Body red with predominant yellow and some black markings. Yellow markings are as follows: Clypeus except a characteristic dark brown mark at middle extends up to base, mandible except reddish-brown teeth, a mark on inter antennal space, inner orbit below ocular sinus, a broad line on temple, a line on ventral side of scape, basal margin of pronotum narrowly, two large marks on scutellum, postscutellum almost entirely, mesopleuron with a spot, two broad marks confluent almost entirely except at apex of middle of propodeum, sides of propodeum broadly, coxa almost entirely, a broad line below forefemur, another narrow line below and a mark at the apex of middle femur, a mark at apex and a line on basal half of gastral petiole on each side, T2 and S2 narrowly at apex, and both tergite and sternite with a large mark on each side at base. Black markings are as follows: Basal margin of clypeus narrowly, a mark on vertex enclosing the ocelli, occiput, pronotum narrowly at base, mesoscutum margined narrowly and broadly at apex, thoracic sutures, metapleuron, mesosternum partly, propodeum (except for the yellow mark) and about half of gastral petiole at base.

Size $(\mathrm{H}+\mathrm{M}+\mathrm{T} 1+\mathrm{T} 2):$ 7.5-8.5 mm.

Distribution: India: Assam, Chhattisgarh, Goa, Jharkhand, Kerala, Madhya Pradesh, Maharashtra, Manipur, Meghalaya, Odisha, Sikkim, Tripura, Uttarakhand, West Bengal. Elsewhere: Bali, Borneo, China, Java, Malay Peninsula, Myanmar, Nepal, Philippine Islands, Sri Lanka, Sumatra, Thailand, Vietnam.

Remarks: Das \& Gupta (1989) previously recorded this species from Raipur of Chhattisgarh.

\section{Ropalidia jacobsoni (du Buysson, 1908) (Image 10)} Icaria jacobsoni du Buysson, 1908: 123. Type: Female, Java: Djakarta (= Batavia) (NMNH).

Ropalidia jacobsoni; Kojima et al. 2007: 386.

Material examined: $14488 / \mathrm{H} 3$ \& 14489/H3, 2 female, 10.i.2013, Kirandul, Dandewada District, Chhattisgarh, India, coll. P. Girish Kumar; 15261/H3, 1 female, 1.xii.2011, Rajadhar forest, Boramdeo WLS, Kabirdham District, Chhattisgarh, India, coll. S.K. Gupta \& party; 15262/H3, 1 female, 22.iii.2012, Dond Nala, Raipur District, Chhattisgarh, India, coll. S.K. Gupta \& party; 15263/H3, 1 female, 4.xii.2011, Rengakhar forest, Boramdeo WLS, Kabirdham District, Chhattisgarh, India, 


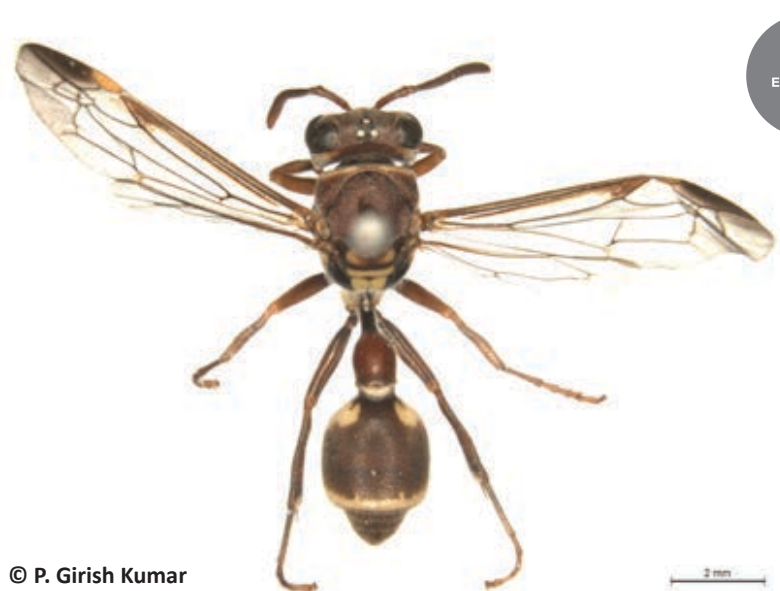

Image 9. Ropalidia stigma (Smith) Female.

coll. S.K. Gupta \& party

Diagnosis: Female: Median furrow of propodeum distinct; T1 in lateral view with dorsal margin more strongly convex in posterior half, highest slightly posterior to level of posterior margin of the sternum.

Colour description: Body reddish-brown with yellow and black markings. Yellow markings as follows: mandible except at tip and at base brown, clypeus except the characteristic black mark, a mark on inter antennal space, inner orbit up to ocular sinus broadly, ventral side of antenna, a narrow line along pronotal carina, basal and lateral margin of scutellum broadly, two large marks on postscutellum, a small mark on the upper part of mesopleuron just below subtegular area, two broad marks on propodeum separated by broad black line along the median groove, inner side of tegula, fore and mid coxae in front, a line on hind coxa laterally, another line below fore femur, a small mark on middle femur laterally, a narrow line on all tibiae above, fore and mid basi-tarsi above, T2 with a large mark on each side at base and a broad apical band on T2 and S2, become narrow towards middle on S2. Black markings as follows: a mark on clypeus at base, supraclypeal area, a large circular spot above each antennal socket, a mark around each ocellus, occiput, basal area of anterior face of pronotum, margins of mesoscutum narrowly but apical margin towards scutellum broadly, a narrow vertical line on scutellum up to one-third from base, propleuron, dorsal metapleuron, ventral metapleuron apically towards mesopleuron broadly, mesosternum, a broad median line separating the two yellow marks and basal and apical margin of propodeum narrowly. Wings transparent hyaline with apical half of radial cell brown, stigma yellow.

Size $(\mathrm{H}+\mathrm{M}+\mathrm{T} 1+\mathrm{T} 2):$ 6-7 mm.

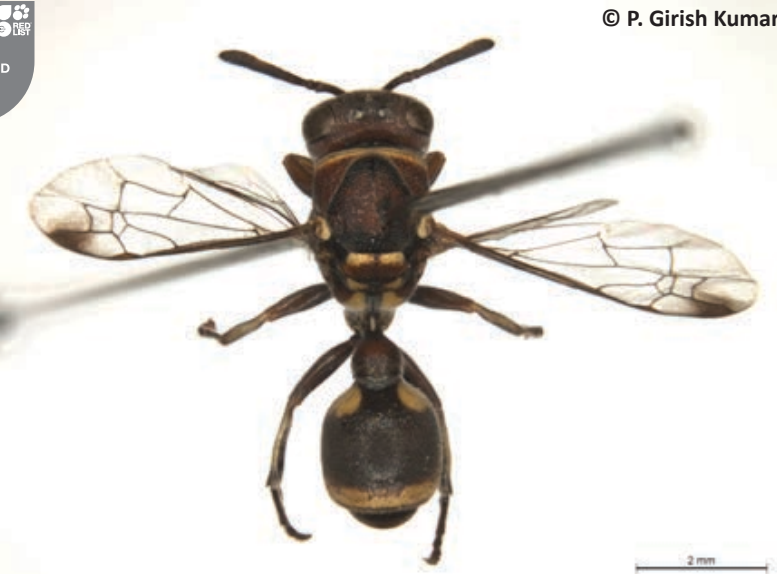

Image 10. Ropalidia jacobsoni (du Buysson) Female.

Distribution: India: Assam, Chhattisgarh (new record), Delhi, Karnataka, Kerala, Maharashtra, Rajasthan, Tamil Nadu, Uttarakhand. Elsewhere: Bangka, Java, Lombok, Myanmar, Sulawesi, Sumatra.

\section{Ropalidia variegata (Smith, 1852) (Image 11)}

Epipona variegata Smith, 1852a: 48. Type: Female, Maharashtra: Poona (NMNH).

Ropalidia variegata: Kojima et al. 2007: 387.

Material examined: 14490/H3, 1 female, 22.viii.2011, Jewra Sirsa, Durg District, Chhattisgarh, India, coll. S.K. Gupta \& party; 14491/H3 \& 14492/H3, 2 female, 29.viii.2011, Bodla forest, Kabirdham District, Chhattisgarh, India, coll. S.K. Gupta \& party; 15264/ H3 to 15266/H3, 3 female, 30.ix.2011, Dheba village, Barnawapara WLS, Raipur District, Chhattisgarh, India, coll. S.K. Gupta \& party.

Diagnosis: Female: Median line of median groove of propodeum indistinct, groove wider in the middle. Median furrow of propodeum indistinct; T1 in lateral view with dorsal margin more or less evenly convex, highest at level of posterior margin of the sternum.

Colour description: Body reddish-brown with predominant yellow markings. Yellow markings as follows: mandible except for dark brown teeth, clypeus except the reddish-brown mark at base, supraclypeal area, inter antennal space, a broad line along inner orbit up to ocular sinus, a broad line on temple, ventral side of antenna, an interrupted line on vertex behind the ocelli (sometimes faint), a spot in between median and lateral ocelli (sometimes faint), a line along pronotal carina, apical and basal margin of scutellum broadly, postscutellum, a mark on mesopleuron, two broad irregular marks on propodeum separated by reddishbrown or blackish-brown line, inner side of tegula, fore 


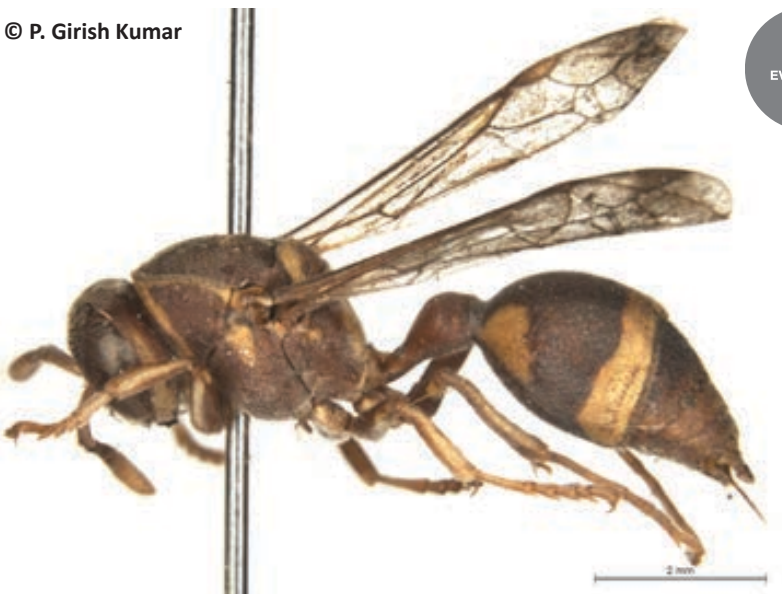

Image 11. Ropalidia variegata (Smith) Female.

and middle coxae in front and greater part of hind coxa, a line on fore and middle femur below and a small mark on hind femur on sides, a line on all tibiae above, two large spots at base of $\mathrm{T} 2$, a broad apical fascia on $\mathrm{T} 2$ and a comparatively small apical fascia on S2. Tarsi reddishbrown with yellowish tinge. Wings transparent hyaline with stigma reddish-brown and apical half of radial cell dark reddish-brown.

Size $(H+M+T 1+T 2): 6-7 \mathrm{~mm}$.

Distribution: India: Bihar, Chhattisgarh (new record), Delhi, Gujarat, Jammu \& Kashmir, Karnataka, Kerala, Madhya Pradesh, Maharashtra, Punjab, Tamil Nadu, Uttarakhand, Uttar Pradesh, West Bengal. Elsewhere: Nepal, Pakistan, Malay Peninsula, Myanmar, Indonesia, China.

\section{Ropalidia cyathiformis (Fabricius, 1804) (Image 12)}

Eumenes cyathiformis Fabricius, 1804: 289. Type: Female, Java (ZMUC).

Ropalidia cyathiformis; Vecht, 1941: 104, 112, 158.

Material examined: 14493/H3, 1 female, 22.iv.1975, Dhamtari, Dhamtari District, Chhattisgarh, India, coll. S.K. Gupta \& party; 14494/H3, 1 female, 14.vii.2011, Bar village, Barnawapara WLS, Raipur District, Chhattisgarh, India, coll. S.K. Gupta \& party; 14495/H3, 1 female, 4.viii.2011, Dheba village, Raipur District, Chhattisgarh, India, coll. S.K. Gupta \& party; 14496/H3 \& 14497/ H3, 2 female, 8.viii.2011, Barbanda, Raipur District, Chhattisgarh, India, coll. S.K. Gupta \& party; 15267/H3 to 15273/H3, 7 female, 7.vi.2012, Rengakhar forest, Boramdeo WLS, Kabirdham District, Chhattisgarh, India, coll. S.K. Gupta \& party.

Diagnosis: Female: First metasomal segment short, in lateral view with dorsal margin arising from posterior margin of basal slit for reception of metasomal suspensory ligament; second segment in lateral view vertically cut off posteriorly.

Colour description: Body reddish-brown with the following yellow markings: mandible except a reddishbrown spot at base and at teeth, clypeus except a median irregular transverse mark, supraclypeal area, inter antennal space continued up to a short distance on frons, a broad line along inner orbit up to ocular sinus, a broad line on temple, ventral side of antenna, pronotum broadly at base and at apical margin towards mesoscutum, two large marks on the sides of scutellum and postscutellum, an elongated spot on the upper half of mesopleuron, two large marks on propodeum separated by median dark brown line, inner side of tegula, fore and middle coxae almost entirely, hind coxa on sides, a line on all femora and tibia, metatarsi of all legs, rest of the legs partly, apical margin and lateral sides of gastral petiole, $\mathrm{T} 2$ and S2 narrowly at apex, and a large mark on each side of $\mathrm{T} 2$ at base. Wings transparent hyaline with stigma yellow and apical half of radial cell dark reddish-brown.

Size (H+M+T1+T2): 6.5-7 mm.

Distribution: India: Arunachal Pradesh, Assam, Bihar, Chhattisgarh, Goa, Karnataka, Kerala, Maharashtra, Uttarakhand. Elsewhere: Bali, Java, Lombok, Malay Peninsula, Myanmar, Nepal, Pakistan, Philippine Islands, Sri Lanka, Sulawesi, Sumba, Thailand, Vietnam.

Remarks: Das \& Gupta (1989) previously recorded this species from Raipur of Chhattisgarh.

\section{Subfamily Vespinae}

This is morphologically the most specialized subfamily of the social wasp. They are popularly known as hornets and yellow jackets. This subfamily is represented by four genera, viz., Dolichovespula Rohwer, 1916, Provespa 
Ashmead, 1903, Vespa Linnaeus, 1758 and Vespula Thompson, 1869 from India of which only Vespa is represented from the state of Chhattisgarh.

\section{Genus Vespa Linnaeus}

Vespa Linnaeus, 1758: 343, 572.

Type species: Vespa crabro Linnaeus, 1758.

Twenty three species are recognised from the world, of which 15 species are known to occur from India. Here the state Chhattisgarh represents only two species (key provided).

\section{Vespa auraria Smith, 1852 (Image 13)}

Vespa auraria Smith, 1852b: 46.

Type: Female, "Northern India" (BMNH).

Material examined: 14454/H3, 1 female, 19.xi.2011, Taraiya Nala, Surguja District, Chhattisgarh, India, coll. S.K. Gupta \& party; 15137/H3, 1 female, 11.xi.2011, Jajawar range, Surguja District, Chhattisgarh, India, coll. A. Raha \& party; 15138/H3, 1 female, 26.xi.2011, Lohartola forest, Boramdeo WLS, Kabirdham District, Chhattisgarh, India, coll. A.K. Sarsavan \& party.

Diagnosis: Sterile Female: Clypeus moderately convex, its apical third depressed and punctate, apical margin emarginate, with distinct lateral lobes; temple less than $1.8 x$ as wide as eye; posterior ocelli less than $3 x$ farther from occiput than from eye; interocular distance shorter than ocellocular distance.

Colour description: Body black with the following reddish-brown markings: head, pronotal collar posteriorly, pronotum, tegula, scutellum, two lateral spots on metanotum and propleuron ventrally. Antenna reddish-brown. Mandible concolorous with clypeus except at apex including teeth black. Mesoscutum black with a U-shaped mark touching scutellum. Fore leg yellowish-brown except inner basal corner of coxa, trochanter and basally in front of femur black. Mid and hind legs black except at apex of femur, apex of tibia and tarsi entirely yellowish-brown to yellow. Bases of $\mathrm{T} 1$ and T2 brownish-black, their margins and the visible part of the following segments yellowish-brown. Base of S2 brownish-black, their margins and visible part of the following sternites yellowish-brown. Wings brownish hyaline. Body covered with fine blackish erect hairs; metasoma with a velvet appearance.

Size $(\mathrm{H}+\mathrm{M}+\mathrm{T} 1+\mathrm{T} 2): 15 \mathrm{~mm}$.

Distribution: India: Arunachal Pradesh, Assam, Chhattisgarh (new record), Jammu \& Kashmir, Jharkhand, Himachal Pradesh, Madhya Pradesh, Meghalaya, Mizoram, Nagaland, Punjab, Sikkim, Tripura, Uttarakhand, Uttar Pradesh, West Bengal.

Elsewhere: Afghanistan, China, Laos, Malaysia, Myanmar, Nepal, Pakistan, Thailand, Yemen.

\section{Vespa tropica haematodes Bequaert, 1936 (Image 14)}

Vespa tropica var. haematodes Bequaert, 1936: 336, 338. Holotype: Female, India: “Kooloo" (MCZ).

Material examined: 14451/H3, 1 female, 20.x.2011, Sankra forest, Sitanadi WLS, Dhamtari District, Chhattisgarh, India, coll. S.K. Gupta \& party; 14452/H3, 1 female, 1.xi.2011, Dullibahal pond side, Barnawapara WLS, Raipur District, Chhattisgarh, India, coll. S.K. Gupta \& party; 14453/H3, 1 female, 26.v.2012, Badalkhol, Jashpur District, coll. A. Raha \& party.

Diagnosis: Sterile female: Body rather large and thick, covered with strong and stiff hairs; clypeus coarsely punctate, apical margin hairy; apical margin of clypeus with a broad emargination, its apico-lateral angle triangular; lower vertical area of pronotum with strong transverse ridges near pronotal pit.

Colour description: Head and antenna reddishbrown; pronotum dorsally and scutellum reddishbrown; mesoscutum anteriorly with two short reddishbrown lines; legs partly reddish-brown; gaster blackishbrown to black except T2 yellow with a slight brown area basally and $\mathrm{S} 2$ yellow with a large brown area basally.

Size $(\mathrm{H}+\mathrm{M}+\mathrm{T} 1+\mathrm{T} 2)$ : 20-21 $\mathrm{mm}$.

Distribution: India: Bihar, Chhattisgarh (new record), Haryana, Himachal Pradesh, Karnataka, Kerala, Odisha, Pondicherry, Sikkim, Tamil Nadu, Tripura, Uttarakhand, West Bengal. Elsewhere: China, Myanmar, Nepal, Pakistan, Sri Lanka, Vietnam.

Key to the species/subspecies of Vespa occurring in Chhattisgarh

(Based on females)

1. Clypeus coarsely punctate; mesosoma predominantly black and head black to red, not marked with yellow (Image 14); metasoma brown or black with T2 yellow (Image 14); apical margin of clypeus with a blunt triangular tooth on each side of the median emargination (Fig. 15); body covered with strong and stiff hairs; T2 almost entirely yellow (Image 14).....

tropica haematodes Bequaert Clypeus sub polished and with scattered punctures; head, mesosoma and metasoma black to brown, with reddish or yellow areas (Image 13); apical margin of clypeus with short broadly rounded lobes on each side of the median emargination (Fig. 14); body hairs fine, shorter and comparatively dense; T2 black with a narrow apical yellow band (Image 13) auraria Smith 


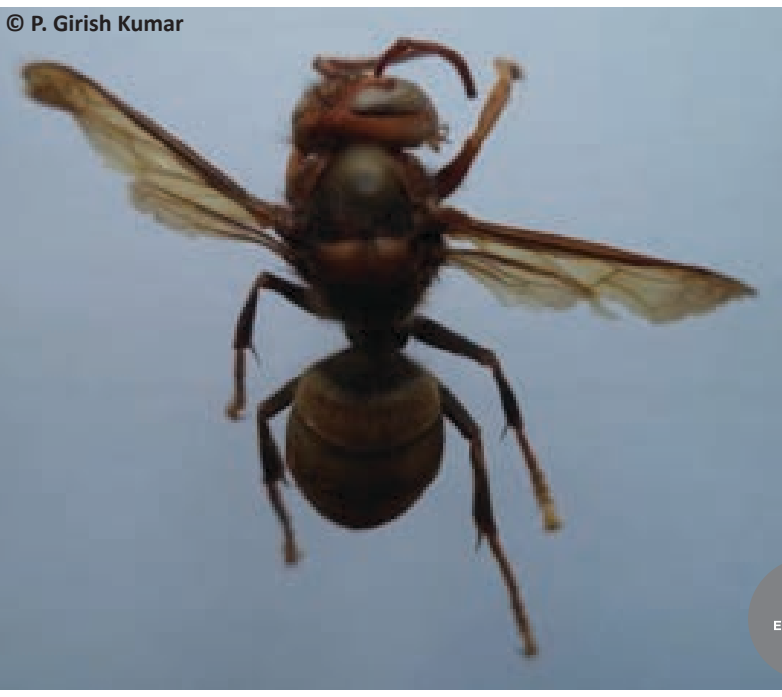

Image 13. Vespa auraria Smith Female.

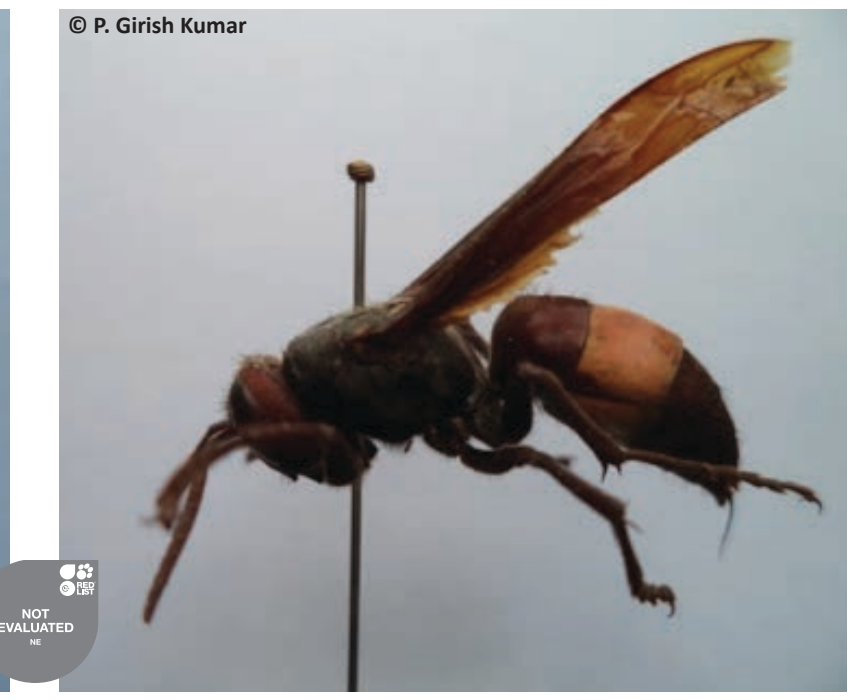

Image 14. Vespa tropica haematodes Bequaert Female.

\section{Subfamily Eumeninae}

This cosmopolitan subfamily consists of about 3000 species in about 150 genera. Adults are small to large and compact to elongate with a sessile to strongly petiolate metasoma. They are commonly known as potter wasps.
They are usually solitary and rarely subsocial. They make burrows in the soil or wood, or exposed mud nests. The younger ones are provisioned with the larvae of Coleoptera, Lepidoptera or Symphyta. Eleven genera and 19 species are recorded from Chhattisgarh.

Key to genera of Eumeninae occurring in Chhattisgarh

1. Metasoma petiolate (Images 23-26, 28-30); T1 in dorsal view with width half or less that of T2, and usually at least twice as long

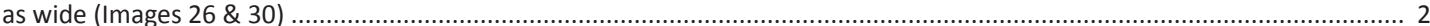
Metasoma not petiolate (Images 15-22, 27, 31-33); T1 with width more than half that of T2, much less than twice as long as wide (Image 22)

2. Propodeum dorsally with elongate fovea from which carina runs to orifice, with dentiform projections above valvulae; axillary fossa narrower than long, slit-like; tegula with narrow posterior lobe which about equals parategula posteriorly; mesepisternum without epicnemial carina; forewing with prestigma longer than pterostigma; female with cephalic foveae

Pareumenes de Saussure

Propodeum without fovea or dentiform projections; axillary fossa oval, broader than long; tegula short, convex and not equalling parategula posteriorly (Fig. 21), or long, with narrow posterior lobe which surpasses parategula posteriorly; other characters partly or completely different ......

Delta de Saussure

3. T1 with section after spiracles shorter than section before spiracles (Image 25)

TI with section after spiracles longer than section before spiracles (Fig. 22)

4. Pronotal carina absent medially; male antenna hooked apically (Fig. 20) ... Phimenes Giordani Soika Pronotal carina present medially; male antennal apex minute (Fig. 19) ............. Oreumenoides Giordani Soika

5. Metanotum with distinct tubercles (Fig. 17) Antepipona de Saussure

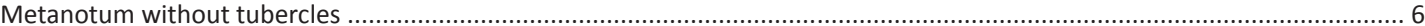

6. Tegula shorter than or equalling parategula posteriorly (Figs. 18 \& 23); axillary fossa in dorsal view much narrower than long,

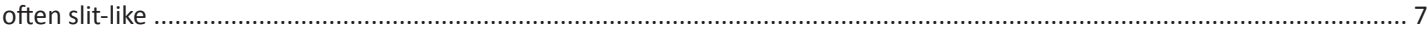
Tegula exceeding parategula posteriorly (Fig. 24); axillary fossa in dorsal view not slit-like, at least as wide as long, oval. ......... 10

7. Scutum posteriorly and scutellum anteriorly impunctate; male midfemur basally emarginate ....................... Rhynchium Spinola Scutum and scutellum punctate; male midfemur not basally emarginate ......................... 8

8. Metanotum flat; propodeal dorsum raised shelf-like to same level; forewing with third submarginal cell separated from apex of marginal cell by about half its length (Fig. 16); male S7 with one or two tubercles ............................ Allorhynchium van der Vecht Metanotum angled; propodeal dorsum not at same level; other characters partly or completely different .............................. 9

9. Mesepisternum without epicnemial carina; propodeum normal, not crenulate or toothed laterally Mesepisternum with epicnemial carina; propodeum crenulate or toothed laterally ........................... Anterhynchium de Saussure

10. Metanotum projecting over propodeum; propodeum with sclerotized dorsolateral projections

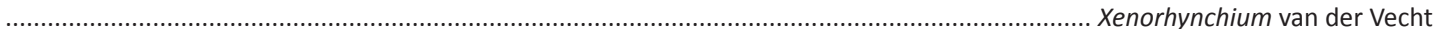
Metanotum with raised disc, in dorsal view with semicircular ridge between the horizontal and vertical surfaces; propodeum without dorsolateral projections Antodynerus de Saussure 


\section{Genus Allorhynchium van der Vecht}

Allorhynchium van der Vecht, 1963: 57, 58, genus.

Type species: Vespa argentata Fabricius, 1804, by original designation.

Eighteen species are recorded under this genus worldwide of which four species namely Allorhynchium anomalum Giordani Soika, 1992, A. argentatum (Fabricius, 1804), A. lugubrinum (Cameron, 1900) and A. metallicum (de Saussure, 1852) are recorded from the Indian subcontinent. Here the state Chhattisgarh represents only two species, namely $A$. argentatum and A. metallicum. A key is provided here for ready reference.

\section{Allorhynchium argentatum (Fabricius, 1804) (Image 15)}

Vespa argentata Fabricius, 1804: 260. Type: Male, "Sumatra" (ZMUC).

Allorhynchium argentatum; Vecht, 1963: 60 (list), fig. $5 a$.

Material examined: 14001/H3, 1 female, 20.x.2011, Sankra forest, Sitanadi WLS, Dhamtari District, Chhattisgarh, India, coll. S.K. Gupta \& party; 14001/H3, 1 female, 1.xi.2011, Dullibahal pond side, Barnawapara WLS, Raipur District, coll. S.K. Gupta \& party.

Diagnosis: Female: Clypeus broadly pyriform, the apex truncate and emarginate; the median area of clypeus not strongly punctate, diameter of punctures almost equal or less than the distance between punctures, interspaces not carinate; pronotal carina strong, complete; epicnemial carina distinct at lower half; outer vein of third submarginal cell of forewing anteriorly very close to apex of marginal cell; T1 and T2 with medium size, closely arranged and moderately dense punctures, interspaces in average equal to punctures, of almost uniform density and thickness except at lateral and apical portions strongly punctured.

Colour description: Body entirely black except a yellow line in between antennal toruli and inner eye margin; tarsal claws blackish-brown; wings dark with purple reflections.

Size $(\mathrm{H}+\mathrm{M}+\mathrm{T} 1+\mathrm{T} 2):$ 12-14 $\mathrm{mm}$.

Distribution: India: Assam, Chhattisgarh (new record), Karnataka, Kerala, Meghalaya, Sikkim, Tamil Nadu, Uttarakhand, Uttar Pradesh, West Bengal.
Elsewhere: Indonesia (Sumatra, Java, Bali, Borneo, Sulawesi), Laos, Malaysia, Nepal, Pakistan, Philippines, Singapore, Thailand.

\section{Allorhynchium metallicum (de Saussure, 1852) (Image 16)}

Rygchium metallicum de Saussure, 1852: 114. Lectotype: Female, Bengal (MP).

Allorhynchium metallicum; Vecht, 1963: 60 (list)

Material examined: 14064/H3, 1 female, 19.viii.2011, Anda village, Durg District, Chhattisgarh, India, coll. S.K. Gupta \& party; 14065/H3 \& 14066/H3, 1 female \& 1 male, 6.xi.2011, Dond forest, Raipur District, Chhattisgarh, India, coll. A.K. Sarsavan \& party; 14067/ H3, 1 female, 7.xi.2011, near Parbatiya waterfalls, Barnawapara WLS, Raipur District, Chhattisgarh, India, coll. S.K. Gupta \& party; 14068/H3 \& 14069/H3, 1 male \& 1 female, 8.xi.2011, Hardinala, Barnawapara WLS, Raipur District, Chhattisgarh, India, coll. A.K. Sarsavan \& party; 14070/H3, 1 female, 22.xi.2011, Jamunpani, Kabirdham District, Chhattisgarh, India, coll. A.K. Sarsavan \& party; 14071/H3, 1 female, 11.i.2013, Bacheli, Dandewada District, Chhattisgarh, India, coll. P. Girish Kumar; 15281/H3, 1 female, 10.xi.2011, Anjani Beat, Surguja District, Chhattisgarh, India, coll. Mandal \& party; 15282/H3, 1 female, 27.xi.2011, Maharajpur, Boramdeo WLS, Kabirdham District, Chhattisgarh, India, coll. A. K. Sarsavan \& party; 15283/H3, 1 female, 28.xi.2011, Nagdhara Nala, Boramdeo WLS, Kabirdham District, Chhattisgarh, India, coll. A.K. Sarsavan \& party; 15284/H3, 1 female, 22.ii.2012, Madosilly Water fall, Gomardo WLS, Raigarh District, Chhattisgarh, India, coll. S.K. Gupta \& party.

Diagnosis: Female: Median area of clypeus not strongly punctate, diameter of punctures almost equal or less than the distance between punctures, interspaces not carinate; T1 and T2 with very small, sparse and very thin punctures except at lateral and apical portions strongly punctured.

Colour description: Body entirely black except a yellow line in between antennal toruli and inner eye margin; tarsal claws blackish-brown; wings fuscohyaline, broadly dark fuscous with purplish reflections along costal margin of forewing.

Key to species of Allorhynchium van der Vecht occurring in Chhattisgarh

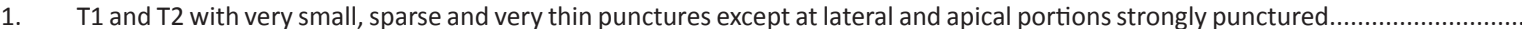

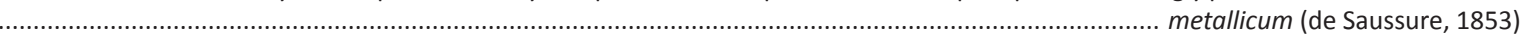

T1 and T2 with medium size, closely arranged and moderately dense punctures, interspaces in average equal to punctures, of almost uniform density and thickness except at lateral and apical portions strongly punctured ................... argentatum (Fabricius, 1804) 


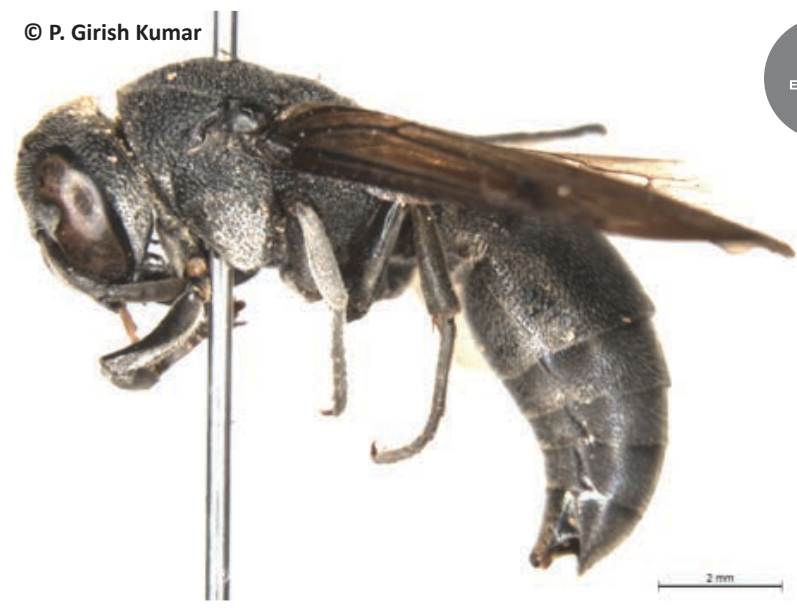

Image 15. Allorhynchium argentatum (Fabricius) Female.

Size (H+M+T1+T2): 10-12 mm.

Male: clypeus more elongate and the apex between two teeth more deeply emarginated than the female; antenna with the last segment hooked apically and almost reaches the apex of tenth antennal segment in curved position; S7 with a distinctly uplifted basal area; basal lamina of volsella armed with a spine; apical tip of aedeagus rounded, parallel spines elongate without hairs. Other characters almost same as in female.

Colour description: similar to that of the female except clypeus with two basal yellow spots sometimes joining and forming a band.

Size $(\mathrm{H}+\mathrm{M}+\mathrm{T} 1+\mathrm{T} 2)$ : 9-11 mm.

Distribution: India: Assam, Chhattisgarh (new record), Delhi, Gujarat, Lakshadweep Islands, Madhya Pradesh, Maharashtra, Sikkim, Tamil Nadu, West Bengal. Elsewhere: Indonesia (Borneo, Moluccas), Maldives Islands, Malaysia (Sarawak), Myanmar, Pakistan, Sri Lanka, Taiwan.

\section{Genus Antepipona de Saussure}

Antepipona de Saussure, 1855: 244.

Type species: Odynerus silaos de Saussure, 1853 , by subsequent designation of van der Vecht, 1967: 30.

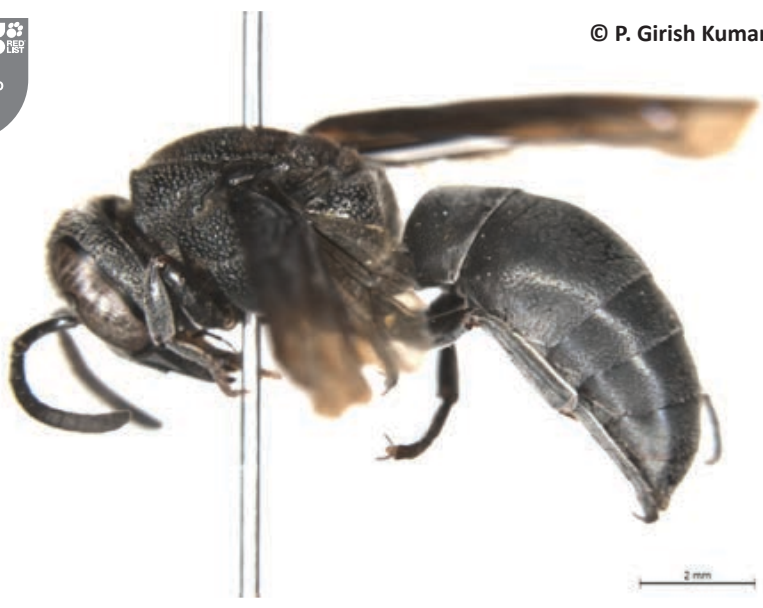

Image 16. Allorhynchium metallicum (de Saussure) Female.

This genus is a widely distributed genus throughout Ethiopian, Oriental and Palaearctic regions of the world. About 26 species with additional eight subspecies are recorded from the Oriental region of which about 20 species with an additional three subspecies are recorded from the Indian subcontinent (Soika, 1981; Gusenleitner, 1996; Kishore \& Narendran, 2002; Kishore, 2004). Three species are present in the state of Chhattisgarh.

\section{Antepipona ceylonica (de Saussure, 1867) (Image 17)}

Odynerus ceylonicus de Saussure, 1867: 12, female, male (in subgenus Leionotus division Epsilon). Type "Ceylon" (MHNG).

Antepipona ceylonica; Giordani Soika, 1981: 207 (key), 215, figs. 7-10 (India; Sri Lanka; Burma).

Material examined: 15291/H3, 1 female, 20.vii.2011, Bar village, Barnawapara WLS, Raipur District, Chhattisgarh, India, coll. S.K. Gupta \& party; 15292/H3 \& 15293/H3, 2 male, 24.xi.2011, Rangpur, Jashpur District, Chhattisgarh, India, coll. Mandal \& party.

Diagnosis: Female: Frons glossy, moderately punctate; pronotal carina well developed on lateral sides, does not reach dorsal side, it bends inwards before

Key to species of Antepipona de Saussure occurring in Chhattisgarh

1. Pronotum with anterior carina well developed on lateral sides, does not reach dorsal side, it bends inwards before reaching dorsal side; dorsal side completely rounded, with an additional carina, thin, in the shape of an arch, often not well distinguishable ....................

Pronotum with regular carina often weak or absent on the dorsal side ceylonica (de Saussure)

2. Pronotum with horizontal series of punctures on middle third of anterior face, close to each other and separated by thin carinae; propodeum with two short horizontal carinae at posterior side ........................................................................... sibilans (Cameron) -Pronotum without such punctures on middle third of anterior face; posterior side of propodeum without horizontal carinae ..... ovalis (de Saussure) 
reaching dorsal side; dorsal side completely rounded.

Colour description: Black, with tarsi brownferruginous. Yellow are: base of mandibles; clypeus with a broad band basal and two apical fused longitudinal lines; lower face of scape; sub quadrate stain on frons except at inter antennal space; a band along the inner orbits of the lower lobes of eyes, which extends up to a little above the ocular sinus; a large line on temple; two large spots on dorsal surface of pronotum; a large round spot on mesepisternum; tegulae, except a transverse brown band; parategula; two large spots on scutellum; two spots on metanotum; two wide longitudinal bands on propodeum; spots on mid and hind coxa; fore and mid femora, except a dark line across the back face; fore and mid tibia, except a dark line across the back face; the outer face of hind tibiae; a thin line across the bottom face of first article of hind tarsi; T1 apically on a band, narrow at the sides; T2 with two large round spots at base and an apical band slightly enlarged in the middle and on the sides; minute specks on the lateral margins ofT3; a thin band, sinuous, almost regular on T4; a round spot on T6; S2 with an apical band slightly enlarged at middle and on sides; T3 with traces of apical band; sometimes even specks on the lateral margins of the apical of S4. Wings subhyaline, slightly browned along the apex.

Size $(\mathrm{H}+\mathrm{M}+\mathrm{T} 1+\mathrm{T} 2): 7 \mathrm{~mm}$.

Male: Apical antennal article hook-like which reaches the middle of the tenth article.

Colour description: Similar to the female except clypeus and interantennal space entirely yellow; apex of T5 with a yellow band; T6 \& T7 without yellow markings.

Size $(\mathrm{H}+\mathrm{M}+\mathrm{T} 1+\mathrm{T} 2): 6-7 \mathrm{~mm}$.

Distribution: India: Chhattisgarh (new record), Karnataka, Kerala, Maharashtra, Odisha, Sikkim, Tamil Nadu, Uttarakhand, Uttar Pradesh. Elsewhere: Myanmar, Sri Lanka.

\section{Antepipona ovalis (de Saussure, 1853) (Image 18)}

Odynerus ovalis de Saussure, 1853: 215. Type, "Les Indes Orientales; Pondichery" (MSNG).

Antepipona ovalis; van der Vecht, 1970: 16, figs. 1-2. Material examined: 15304/H3, 1 female, 13.vi.2012, Sihawal Sagar, Achanakmar WLS, Bilaspur District, Chhattisgarh, India, coll. A. Raha \& party; 15305/H3, 1 male, 12.xii.2011, Lamni village, Jagadalpur, Bastar District, Chhattisgarh, India, coll. A. Raha \& party.

Diagnosis: Female: Clypeus very wide, weakly emarginated, with a few small punctures; mesopleuron moderately punctate; metanotum with very small teeth, close to lateral metanotal margin; posterior side of propodeum without carinae; S2 not bulging at base.

Colour description: Black, with apex of mandible, lower face of funicular segments and tarsal segments ferruginous. Yellow are: base of mandible; clypeus; scape except a black line on upper surface toward apex; quadrangular mark on lower half of front, base distinctly wider than apex; large stain on ocular sinus, which bulges out to lower frons, reaches up to clypeus; a large stain on temple; broad band on dorsal surface of pronotum; broad mark on mesepisternum; scutellum except posterior margin; metanotum; two large spots on propodeum; tegula; parategula; front face of all coxae; fore and mid femora; hind femur posteriorly; all tibiae; T1 with a large apical band, wider at middle, together with two large lateral spots; T2 with two large lateral spots at base, and it connected to an apical band, which greatly enlarged at middle and on sides; T3-T5 with comparatively narrow band, but strongly dilated at sides; a round spot on T6; two broad spots at base of S2; large apical band, strongly enlarged at middle and sides on S2-S4. Wings slightly browned.

Size $(\mathrm{H}+\mathrm{M}+\mathrm{T} 1+\mathrm{T} 2): 7 \mathrm{~mm}$.

Male: Clypeus much wider than long, with a large emargination at apex; last antennal article of medium size, slightly arched, rapidly narrowed from base to apex, which reaches the end of tenth article.

Size $(\mathrm{H}+\mathrm{M}+\mathrm{T} 1+\mathrm{T} 2): 6 \mathrm{~mm}$.

Distribution: India: Chhattisgarh (new record), Karnataka, Kerala, Maharashtra, Odisha, Pondicherry, Tamil Nadu, Uttarakhand, West Bengal. Elsewhere: Afghanistan, Sri Lanka.

\section{Antepipona sibilans (Cameron, 1903) (Image 19)}

Odynerus sibilans Cameron, 1903: 129, male, Barrackpore" (OUM).

Antepipona sibilans; Giordani Soika, 1981: 206, 207 (key), 225, figs. 23-28 (syn.: A. deflendiformis; India: Deesa, Quetta, Abu).

Material examined: 15294/H3, 1 male, 6.iv.1990, Jhilmili village, Surguja District, Chhattisgarh, India, coll. H.S. Sharma \& party; 15295/H3, 1 male, 2.iv.2012, Pakchi Vihar, Barnawapara WLS, Raipur District, Chhattisgarh, India, coll. S.K. Gupta \& party; 15296/H3, 1 female, 2.v.2012, Furfundi, Barnawapara WLS, Raipur District, Chhattisgarh, India, coll. S.K. Gupta \& party; 15297/H3 to 15299/H3, 1 female \& 2 male, 27.v.2012, Badalkhol, Jashpur District, Chhattisgarh, India, coll. A. Raha \& party; 15300/H3 \& 15301/H3, 2 female, 30.v.2012, Kudmura, Korba District, Chhattisgarh, India, coll. A. Raha \& party; 15302/H3, 1 male, 8.vi.2012, Khara, Kawardha District, Chhattisgarh, India, coll. A. Raha \& party; 15302/H3, 1 


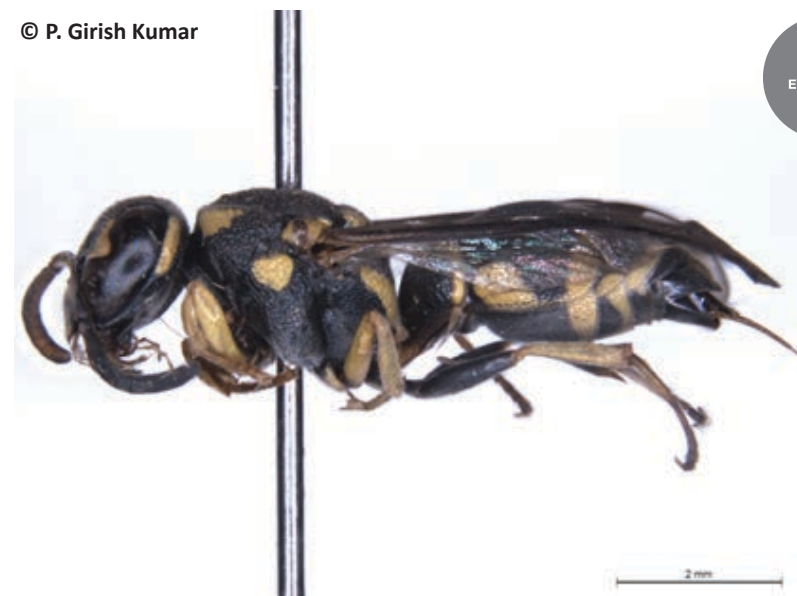

Image 17. Antepipona ceylonica (de Saussure) Female.

male, 8.vi.2012, Khara, Kawardha District, Chhattisgarh, India, coll. A. Raha \& party; 15303/H3, 1 female, 11.vi.2012, Chhaparwa, Bilaspur District, Chhattisgarh, India, coll. A. Raha \& party.

Diagnosis: Female: Clypeus wider than long, without longitudinal carinae; metanotal teeth close to metanotal margin; distance between metanotal teeth twice as much distance between each tooth and lateral metanotal margin; head and mesosoma densely punctate; pronotum with horizontal series of punctures on middle third of anterior face, close to each other and separated by a thin carina.

Colour description: Black, with apex of mandible, lower face of funicular segments ferruginous. Yellow are: base of mandible; clypeus except a black spot at middle; scape except a black line on upper surface toward apex; front, except interantennal space and two black spots, which start from antennal toruli and directed obliquely upward; a large stain on temple; broad band on dorsal surface of pronotum; almost all of upper mesepisternum; scutellum except posterior margin; metanotum; two large spots on propodeum, occupying entire dorsal faces; tegula except a brown spot medially; parategula; front face of all coxae; fore and mid femora; hind femur posteriorly; all tibiae; T1 with a large apical band, wider at middle, together with two large lateral spots; T2 with two large lateral spots at base, and an apical band, which greatly enlarged at middle and on sides; T3 with a narrow band, but strongly enlarged at sides; a band almost regular on T4; a stain at middle of apical margin of T5; a round spot on T6; large apical band, strongly enlarged at middle on S2-S4, wider on S2 and narrower on next two. Wings moderately browned, more heavily along apical half of marginal cell.
Size $(\mathrm{H}+\mathrm{M}+\mathrm{T} 1+\mathrm{T} 2)$ : 6-6.5 mm.

Male: Clypeus wider than long, with apical emargination moderately deep, punctures about as that of front, but a little less weak. Apical antennal article hooked, and its apex reaching the middle of tenth article. Mandible and clypeus entirely yellow.

Size (H+M+T1+T2): 5.5-6 mm.

Distribution: India: Chhattisgarh, Gujarat, Karnataka, Maharashtra, Odisha, Pondicherry, Rajasthan, Tamil Nadu, West Bengal. Elsewhere: Nepal; Pakistan.

Remarks: Giordani Soika (1981) reported this species from Raipur of the state of Chhattisgarh.

\section{Genus Anterhynchium de Saussure \\ Anterhynchium de Saussure, 1863: 205}

Type species: Rygchium synagroides de Saussure, 1852, by subsequent designation of van der Vecht, 1963: 73.

Forty four species are recorded under this genus from the world of which five species namely Anterhynchium (A.) abdominale (Illiger), A. (A.) mellyi (de Saussure), $A$. (Dirhynchium) coracinum Vecht, $A$. (D.) flavolineatum (Smith) and $A$. (D.) flavomarginatum (Smith) are recorded from the Indian subcontinent (Kumar, 2013b). Here the state Chhattisgarh represents only 2 species, namely $A$. (A.) abdominale and $A$. (A.) mellyi with an additional subspecies of $A$. (A.) abdominale. A key to species is provided here for ready reference.

\section{Anterhynchium abdominale (IIliger, 1802)}

Diagnosis: Clypeus with weak punctures, from the middle of clypeus to apex with few irregular longitudinal striations; narrow basal part of S1 smooth; gastral tergites only finely punctate at base; basal two thirds of 
Key to species and subspecies of Anterhynchium de Saussure occurring in Chhattisgarh

1. Basal two thirds of second gastral tergite distinctly punctate, except in the middle, the interspaces generally larger than the

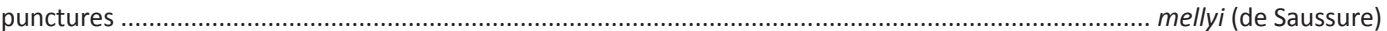
Basal two thirds of second gastral tergite very finely and shallowly punctate, the interspaces everywhere much larger than

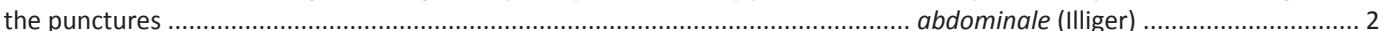

2. Gaster (Image 20a) mostly red except the following black markings: a narrow transverse band at the apex of T1, a spot on the middle of posterior apex of the T2 and S2 (sometimes T3, T4, T5 and S3, S4, S5 also), last tergite and sternite entirely black.

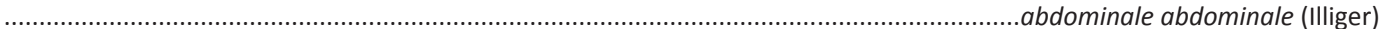
Gaster (Image 20b) entirely black (in some specimens apical margins of T2 and following tergites, as well as sides of T1 and T2 partly blackish brown) ...................................................................................... abdominale bengalense (de Saussure)

T2 very finely and shallowly punctate, the interspaces everywhere much larger than the punctures; mandibles of male deeply emarginate on inner side near the middle.

\section{0a. Anterhynchium abdominale abdominale (Illiger, 1802) (Image 20a)}

Vespa abdominalis Illiger, 1802: 192. Type: "Bengalen" (?ZMB).

Anterhynchium abdominale; Vecht, 1963: 75, fig. 5e.

Material examined: 14498/H3 to 14504/H3, 1 female \& 6 male, 1.vii-13.viii.2011, Bar village, Barnawapara WLS, Raipur District, Chhattisgarh, India, coll. S.K. Gupta \& party; 14505/H3, 1 male, 17.vii.2011, Bar village, Barnawapara WLS, Raipur District, Chhattisgarh, India, coll. S.K. Gupta \& party; 14506/H3, 1 male, 16.viii.2011, Bar village, Barnawapara WLS, Raipur District, Chhattisgarh, India, coll. S.K. Gupta \& party; 14507/ H3, 1 female, 18.x.2011, Godhmali, Gariaband District, Chhattisgarh, India, coll. S.K. Gupta \& party.

Colour description: Female: Head and mesosoma black; metasoma dull orange-red with variegated black markings as follows: the basal segment with a transverse black apical band, T2 with or without a transverse black spot in the middle of its apical margin, the remaining segments usually orange-red except last segment black, gastral sternites usually orange-red with varying degrees of black colour except last segment entirely black. Brown colouration as follows: ventral side of antenna and tarsal segments (sometimes black). Wings dark fuscous with purple reflections.

Size $(\mathrm{H}+\mathrm{M}+\mathrm{T} 1+\mathrm{T} 2):$ 12-14.5 mm.

Male: Clypeus more elongate and the apex between two teeth more deeply emarginated than female; antenna with the last segment hooked apically and almost reaches the apex of tenth antennal segment in curved position; apical tip of aedeagus rounded, parallel spines elongate without hairs.

Colour description: Colour pattern is almost the same as that of the female except clypeus almost entirely yellow with the lateral and apical margins black and scape in front yellow.

Size $(\mathrm{H}+\mathrm{M}+\mathrm{T} 1+\mathrm{T} 2)$ : 9-12 $\mathrm{mm}$.

Distribution: India: Chhattisgarh, Kerala, Rajasthan, Sikkim, Tamil Nadu, Uttar Pradesh, West Bengal. Elsewhere: Myanmar, Pakistan, Sri Lanka.

Remarks: Dover \& Rao (1922) previously recorded

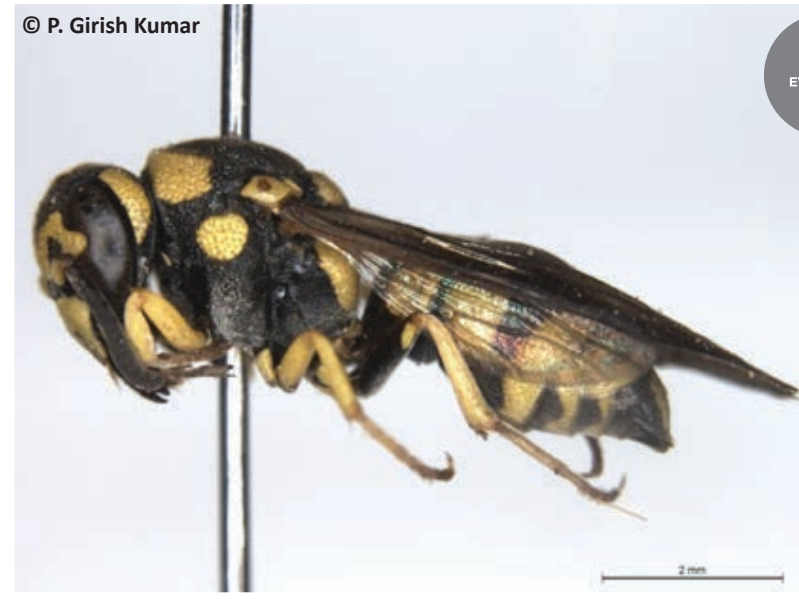

Image 19. Antepipona sibilans (Cameron) Female.

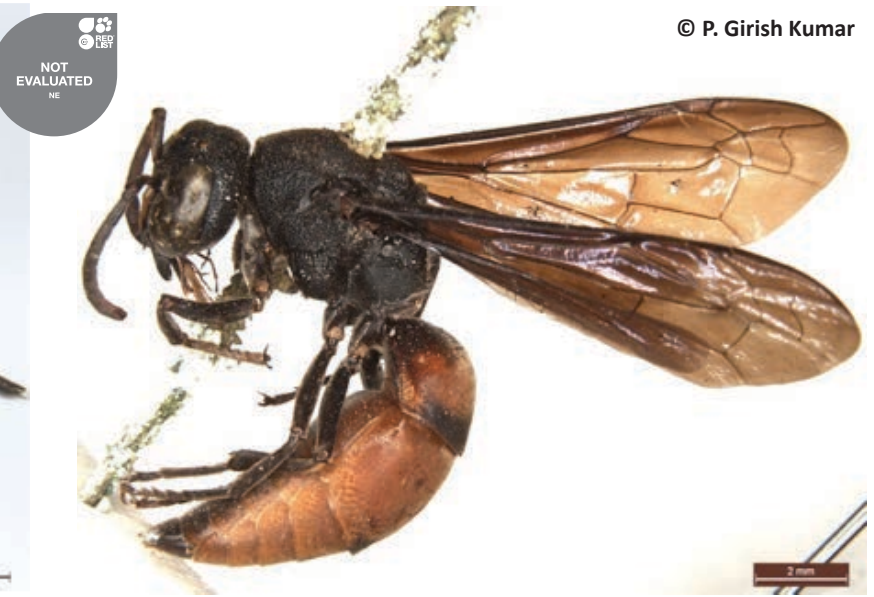

Image 20a Anterhynchium abdominale abdominale (Illiger) Male. 
this species from Bilaspur of Chhattisgarh.

20b. Anterhynchium abdominale bengalense (de Saussure, 1852) (Image 20b)

Rhynchium bengalense de Saussure, 1855: 176. Type:

"Le Bengale" (MP).

Anterhynchium abdominale bengalense; Vecht, 1963: 76.

Material examined: 14508/H3, 1 male, 11.viii.2011, Bar village, Barnawapara WLS, Raipur District, Chhattisgarh, India, coll. A. K. Sarsavan \& party; 14509/ H3, 1 male, 14.viii.2011, Janakpur, Koriya District, Chhattisgarh, India, coll. A. Raha \& party; 15290/H3, 1 female, 3.ii.2012, Bas Nala, Barnawapara WLS, Raipur District, Chhattisgarh, India, coll. A. Raha \& party.

Colour description: Female: Body black. Wings dark fuscous with violet reflections.

Size $(\mathrm{H}+\mathrm{M}+\mathrm{T} 1+\mathrm{T} 2)$ : 13-14 mm.

Male: Body black (sometimes ventral side of antenna, apical tarsal segments and lateral sides of tergites reddish-brown except last segment). Clypeus almost entirely yellow with the lateral and apical margins black and scape in front yellow. Wings dark fuscous with violet reflections.

Size $(\mathrm{H}+\mathrm{M}+\mathrm{T} 1+\mathrm{T} 2):$ 11-11.5 mm.

Distribution: India: Bihar, Chhattisgarh (new record), Kerala, Punjab, Rajasthan, Uttar Pradesh, West Bengal.

\section{Anterhynchium mellyi (de Saussure, 1852) (Image 21)}

Rygchium mellyi de Saussure, 1852: 116.

Type: Female, "Les Indes, La Chine" (MP and MHNG). Anterhynchium mellyi; Vecht, 1963: 76.

Material examined: 14510/H3, 1 male, 14.vii.2011,
Bar village, Barnawapara WLS, Raipur District, Chhattisgarh, India, coll. S.K. Gupta \& party; 14511/H3 \& 14512/H3, 2 male, 22.vii.2011, Barnawapara Camp, Barnawapara WLS, Raipur District, Chhattisgarh, India, coll. S.K. Gupta \& party; 14513/H3, 1 male, 31.vii.2011, Achanakpur, Barnawapara WLS, Raipur District, Chhattisgarh, India, coll. S.K. Gupta \& party; 14514/H3, 1 male, 27.v.2012, Pakhridhab, Badalkhol, Jashpur District, Chhattisgarh, India, coll. A. Raha \& party; 15285/H3, 1 male, 24.iii.2012, Bar village, Barnawapara WLS, Raipur District, Chhattisgarh, India, coll. S.K. Gupta \& party; 15286/H3, 1 male, 8.v.2012, Uraonpara, Guru Ghasidas NP, Koriya District, Chhattisgarh, India, coll. S.K. Gupta \& party; 15287/H3, 1 male, 21.v.2012, Lakshman Jhiria, Guru Ghasidas NP, Koriya District, Chhattisgarh, India, coll. S.K. Gupta \& party; 15288/H3, 1 female, 16.ix.2012, Tara, Surguja District, Chhattisgarh, India, coll. A. Raha \& party; 15289/H3, 1 female, 15.v.2013, Kundraghat, Tamor Pingla WLS, Balrampur District, Chhattisgarh, India, coll. A. Raha \& party.

Diagnosis: Female: Clypeus with weak punctures, from the middle of clypeus to apex with a few irregular longitudinal striations; frons closely, strongly and rugosely punctured; anterior face of pronotum smooth without punctures; pronotal carina strong and almost reaching the lateral margin of pronotum; epicnemial carina distinct, complete; dorsolateral margin of propodeum ending posteriorly with a sharp teethlike projection; punctures on dorsolateral area strong and rugose; posterior concave area of propodeum with irregular transverse striations; lateral sides of propodeum transversely striated with a few rugose punctures at upper and posterior sides; forewing with prestigma $0.7 x$ pterostigma; basal two thirds of $\mathrm{T} 2$

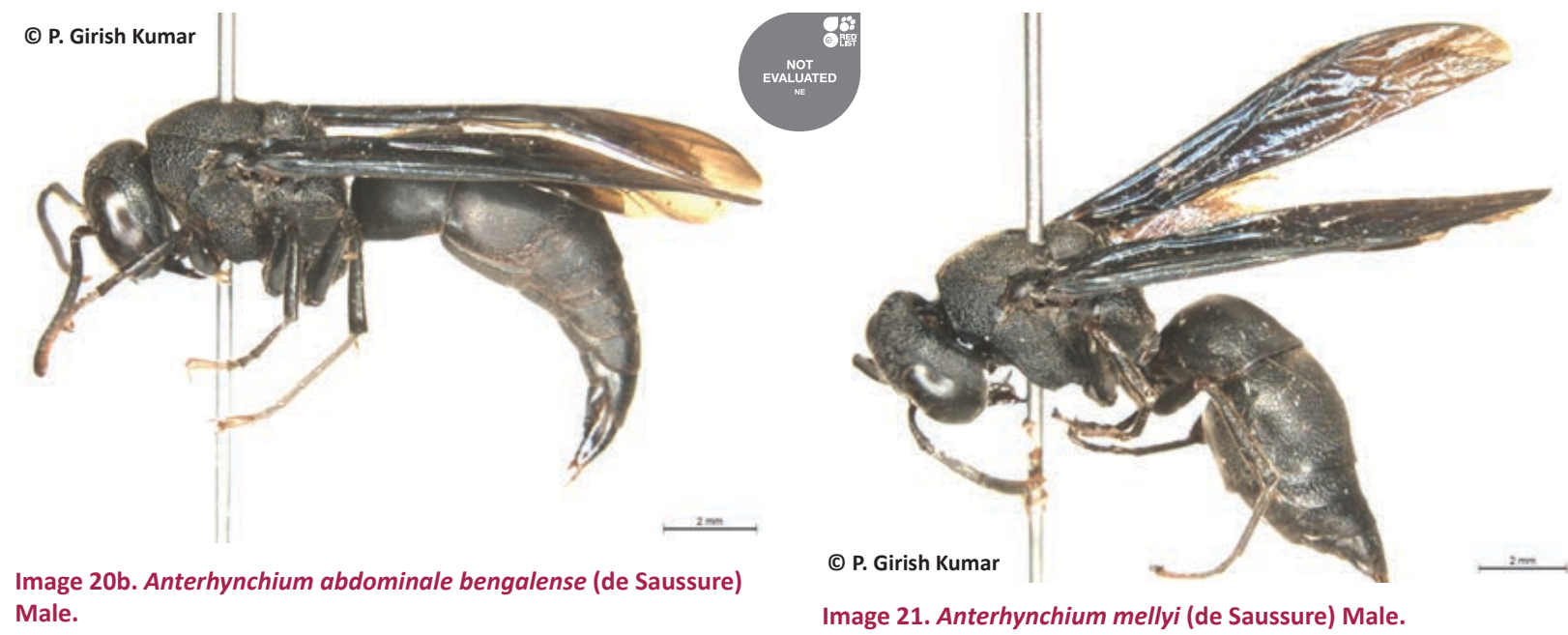


very finely and shallowly punctate, the interspaces everywhere much larger than the punctures, coarsely punctate near the apical margin.

Colour description: Body entirely black. Wings fuscous with purple reflections.

Size $(\mathrm{H}+\mathrm{M}+\mathrm{T} 1+\mathrm{T} 2)$ : 14-15 mm.

Male: Clypeus with weak punctures, from the middle of clypeus to apex with a few irregular longitudinal striations; narrow basal part of S1 smooth; gastral tergites only finely punctate at base; basal two thirds of $\mathrm{T} 2$ distinctly punctate, except in the middle the interspaces generally larger than the punctures; clypeus more elongate and the apex between two teeth more deeply emarginated than the female; antenna with the last article hooked apically and almost reaches the apex of tenth antennal segment in curved position; apical tip of aedeagus rounded, parallel spines elongate without hairs.

Colour description: Body black except clypeus almost entirely yellow with the lateral and apical margins black and scape in front yellow. Wings fuscous with purple reflections.

Size $(\mathrm{H}+\mathrm{M}+\mathrm{T} 1+\mathrm{T} 2):$ 12-12.5 mm.

Distribution: India: Chhattisgarh (new record), Uttar Pradesh, West Bengal. Elsewhere: China, Myanmar, Thailand, Vietnam (Tonkin).

\section{Genus Antodynerus de Saussure}

\section{Antodynerus de Saussure, 1855: 287}

Type species: "Odynerus punctum (Fabricius)" sensu de Saussure, 1853 [= Vespa flavescens Fabricius, 1775], by subsequent designation of van der Vecht, 1959 (1958): 238.

Fifty four species with numerous subspecies are recorded under this genus worldwide. Three species with one additional subspecies namely Antodynerus flavescens flavescens (Fabricius, 1775), A.flavescens karachiensis Giordani Soika, 1970, A. limbatus (de Saussure, 1852) and $A$. punctatipennis (de Saussure, 1853) are reported from the Indian subcontinent. Here the state Chhattisgarh represents only one species, namely $A$. flavescens flavescens.

\section{Antodynerus flavescens flavescens (Fabricius, 1775) (Image 22)}

Vespa flavescens Fabricius, 1775: 370. Lectotype: Male, "In India Orientali" (ZMUC).

Antodynerus flavescens flavescens; Kumar \& Carpenter, 2013: 269, figs. 1-8.

Material examined: 14133/H3, 1 female, 28.viii.2011, Palak village, Kabirdham District, Chhattisgarh, India, coll. S.K. \& party; 14134/H3 \& 14135/H3, 1 female \& 1 male, 7.xi.2011, near Parbatiya Waterfalls, Barnawapara WLS, Raipur District, coll. S.K. Gupta \& party.

Diagnosis: Female: Median area of propodeum with a shallow narrow fovea from which median carina runs to orifice, without distinct transverse striae; posterolateral margin of propodeum rounded, without a strong transversely carinate projection, below that with evanescent transverse striae; frons sparsely punctured, diameters of punctures less than the distance between punctures; ocellar area almost smooth without punctures; vertex with moderately strong punctures except at middle and area towards occipital carina smooth.

Colour description: Body brownish-red with yellow, white and black marks. Usually brownish-red colour mixed with yellow and white marks in many areas. Generally the yellow colour as follows: mandible except at lateral and apical margins brown, basal and lateral sides of clypeus (rarely entirely yellow), interantennal space (rarely brown or black), inner and outer eye margins, lower sides of temple and occiput, ventral side of scape, tegula except inner white margin (sometimes entirely yellow or yellowish-brown), T2 except at base black, S2 almost entirely. Generally the white (sometimes whitishyellow) markings as follows: throughout pronotal carina, inner side of tegula, sides of scutellum, posterior side of metanotum, a spot on mesopleuron below tegula. Black markings as follows: inner side of ocellar area (sometimes absent), basal area of tergites which are more prominent on T2 and T3, area in between S1 and S2. Legs pale brown inter mixed with yellow. Wings hyaline with pterostigma and apex of median cell yellow and a dark infumation at apex of radial cell.

Size $(\mathrm{H}+\mathrm{M}+\mathrm{T} 1+\mathrm{T} 2)$ : 9-11 $\mathrm{mm}$.

Male: Antenna with last atricle hook-like, almost reaching to the base of eleventh antennal segment in curved position; apical tip of aedeagus rounded, parallel spines elongate without hairs. Other characters almost same as in the female.

Colour description: Colour pattern is almost same as that of the female except clypeus entirely and a transverse band at lower frons yellow.

Size $(\mathrm{H}+\mathrm{M}+\mathrm{T} 1+\mathrm{T} 2)$ : 8.5-9.5 mm.

Distribution: India: Bihar, Chhattisgarh, Goa, Karnataka, Maharashtra, Odisha, Uttarakhand, Uttar Pradesh, West Bengal. Elsewhere: Bangladesh.

Remarks: Kumar \& Carpenter (2013) recorded this species from Palak of Kabirdham district Barnawapara Wildlife Sanctuary of Raipur district of Chhattisgarh. 


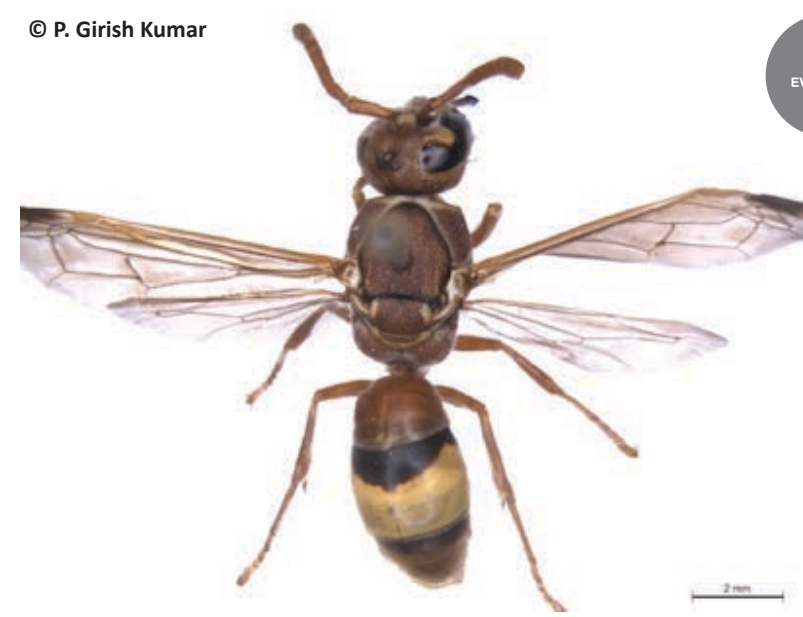

Image 22. Antodynerus flavescens flavescens (Fabricius) Female.

\section{Genus Delta de Saussure}

Delta de Saussure, 1855: 130, 132, 143.

Type species Vespa maxillosa De Geer, 1775 [= Vespa emarginata Linnaeus, 1758], by subsequent designation of Bequaert, 1925: 137.

Twenty seven species with several additional subspecies are recorded under this genus from Oriental region of which seven species with three additional subspecies are recorded from India. Four species, namely, Delta conoideum (Gmelin, 1790), D. dimidiatipenne (de Saussure, 1852), D. esuriens (Fabricius, 1787) and D. pyriforme pyriforme (Fabricius, 1775) are recorded from Chhattisgarh.

\section{Delta conoideum (Gmelin, 1790) (Image 23)}

Vespa conica Fabricius, 1787: 293. Syntype: Female. China (BMNH).

Delta conoideum; Gusenleitner, 2006: 694.

Material examined: 14529/H3, 1 female, 2.viii.2011, Lalbandha pondside, Raipur District, Chhattisgarh, India, coll. S.K. Gupta \& party; 14530/H3, 1 female, 18.x.2011, Kodhmali, Gariaband District, Chhattisgarh, India, coll. S.K. Gupta \& party; 14531/H3, 1 female,

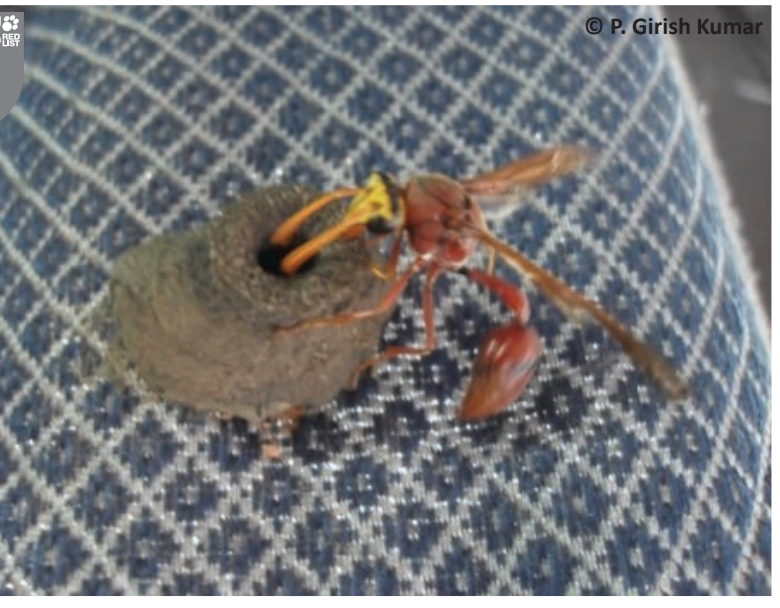

Image 23. Delta conoideum (Gmelin) Female.

25.v.2012, Bardand, Badalkhol, Jashpur District, Chhattisgarh, India, coll. A. Raha \& party; 15115/H3, 1 female, 26.iv.2012, Domarpani, Barnawapara WLS, Raipur District, Chhattisgarh, India, coll. S.K. Gupta \& party; 15116/H3, 1 female, 11.v.2012, Jagadalpur, Bastar District, Chhattisgarh, India, coll. R.P. Gupta \& party; 15117/H3, 1 female, 7.vi.2012, Rengakhar forest, Boramdeo WLS, Kabirdham District, Chhattisgarh, India, coll. Kailash Chandra \& party; 15118/H3, 1 female, 30.v.2012, Kudmura, Korba District, Chhattisgarh, India, coll. A. Raha \& party; 15119/H3 \& 15120/H3, 2 male, 27.iii.2014, Kudmura, Korba District, Chhattisgarh, India, coll. E.E. Jehamalar \& party.

Diagnosis: Female: Head above the antenna and mesosoma closely and lightly punctured; clypeus pyriform, its apex truncate; metasoma smooth and shining with the surface minutely aciculate.

Colour description: Head yellow except mandibles and antenna reddish, a broad transverse band across the apex between the tops of the eyes black, black mark extends behind the vertex to occiput; thorax dark red with black patches on mesoscutum, metapleuron and median area of propodeum, propleuron entirely black;

Key to species and subspecies of Delta occurring in Chhattisgarh

1. Posterior third of T2 and visible part of remaining gastral tergites yellow (Images $25 \& 26)$............................................... 2 Posterior third of T2 and visible part of remaining gastral tergites black or red or black with subapical interrupted yellow bands

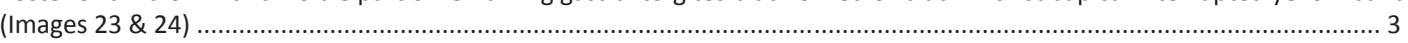

2. Gastral petiole without apical yellow band (Image 26); body large and robust (usually more than 20 mm); mesoscutum yellow anteriorly (Image 26); forewing without a brown infumation on radial cell .................... pyriforme pyriforme (Fabricius, 1775) Gastral petiole with apical yellow band (Image 25); body small and slender (usually less than $20 \mathrm{~mm}$ ); mesoscutum either red or red variegated with black markings (Image 25); forewing with a brown infumation on radial cell ...... Apical half of second gastral tergite and whole of the remaining tergites black (Image 24); in female, clypeus and lower half of frons red ....................................................................................................................... dimidiatipenne (de Saussure, 1852) Apical half of second gastral tergite and whole of the remaining tergites red (Image 23); in female, clypeus and lower half of

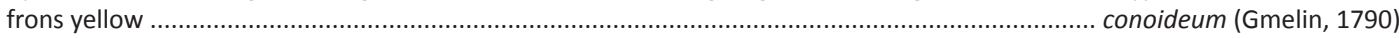


legs pale reddish; gaster dark red with base of the T2 and a short transverse medially interrupted band on its middle above black; forewing basally flavohyaline and apically fuscohyaline, with a slight purplish reflection.

Size $(\mathrm{H}+\mathrm{M}+\mathrm{T} 1+\mathrm{T} 2)$ : 23-26 mm.

Male: Last antennal article hooked apically, hook long, curved and pointed, in curved position it almost reaches the apex of $9^{\text {th }}$ antennal article; S7 with a deep median longitudinal groove; Male comparatively smaller and slighter than female. Other characters almost same as that of the female.

Size $(\mathrm{H}+\mathrm{M}+\mathrm{T} 1+\mathrm{T} 2):$ 16-18 $\mathrm{mm}$.

Distribution: India: Arunachal Pradesh, Chhattisgarh (new record), Odisha, Sikkim, Tamil Nadu, Tripura, Uttar Pradesh. Elsewhere: Arabia, China, Malaysia, Myanmar, Pakistan, Sri Lanka, Thailand.

\section{Delta dimidiatipenne (de Saussure, 1852) (Image 24)}

Eumenes dimidiatipennis de Saussure, 1852: 51. Syntype: Female, Male, "Djidda (Arabie), les Indes Orientales, I'Egypte" (MP).

Delta dimidiatipenne; Blüthgen, 1961: 279.

Material examined: 13097/H3, 1 female, 24.iv.1975, Raipur Ganj, Raipur district, Chhattisgarh, India, coll. S.K. Gupta \& party; 15121/H3, 1 female, 31.iii.2014, Chapri village, Kabirdham district, Chhattisgarh, India, coll. E.E. Jehamalar \& party.

Diagnosis: Female: Clypeus smooth, its anterior margin concave at apex; frons and ocular sinus closely and strongly punctured; vertex and temple with minute punctures.

Colour description: Head obscure dull red with following black markings: a broad band on vertex including upper half of frons, a vertical line to each antennal toruli, extending behind vertex to outer side of temple and to occiput; dorsal side of apical four segments of antenna. Mesosoma dull red with highly variable black patches as follows: mesoscutum usually entirely black except parategula; a black margin on scutellum anteriorly; propleuron usually black; mesopleuron usually with large black area except a dull red patch below tegula and another red mark at lower side near to mid coxa; metapleuron usually with large black area except a red patch on upper metapleuron; median groove of propodeum sometimes black; metasoma dull red except the following black markings: base of petiole, apical half of second tergite and sternite, whole of the remaining tergites and sternites. Wings ferruginous with apical half of forewing fuscous having a purple reflection.
Size $(\mathrm{H}+\mathrm{M}+\mathrm{T} 1+\mathrm{T} 2): 21 \mathrm{~mm}$.

Distribution: India: Arunachal Pradesh, Chhattisgarh, Delhi, Gujarat, Himachal Pradesh, Jammu \& Kashmir, Jharkhand, Kerala, Maharashtra, Punjab, Rajasthan, Uttarakhand, Uttar Pradesh. Elsewhere: Afghanistan, Africa, Algeria, Arabia, Canary Islands, Central Africa, Central Sahara, Chad, Djibouti, Egypt, Eritrea, Ethiopia, Iran, Madagascar, Mauritania, Nepal, Niger, Pakistan, Palestine, Somalia, South Africa, Sudan, Syria, Turkey, Uganda, Yemen.

Remarks: Kumar (2012a) previously recorded this species from Raipur Ganj of Chhattisgarh.

\section{Delta esuriens (Fabricius, 1787) (Image 25)}

Vespa esuriens Fabricius, 1787: 293. Syntype, Sex not mentioned, India (BMNH).

Delta esuriens: Giordani Soika, 1992: 62.

Material examined: 13005/H3, 1 female, 22.iv.1975, Kukrel, Dhamtari District, Chhattisgarh, India, coll. S.K. Gupta \& party; 13006/H3 \& 13007/H3, 2 female, 1.i.1981 14.xii.1981, Sonpur \& Chitrakoot, Bastar District, Chhattisgarh, India, coll. M.S. Shishodia \& party; 14515/H3 \& 14516/H3, 2 male, 12.vii.2011, Lalbandha pond side, Raipur District, Chhattisgarh, India, coll. S.K. Gupta \& party; 14517/H3, 1 male, 26.v.2012, Manda Tengna, Badhalkhol, Jashpur District, Chhattisgarh, India, coll. A. Raha \& party; 15122/H3, 1 female, 18.x.2011, Sunwahi forest, Boramdeo WLS, Kabirdham District, Chhattisgarh, India, coll. S.K. Gupta \& party; 15123/H3, 1 female, 5.i.2012, Jagadalpur, Bastar District, Chhattisgarh, India, coll. R.P. Gupta \& party; 15124/H3, 1 female, 25.i.2012, Barbanda, Barnawapara WLS, Raipur District, Chhattisgarh, India, coll. S.K. Gupta \& party; 15125/H3, 1 female, 30.v.2012, Kudmura, Korba District, Chhattisgarh, India, coll. A. Raha \& party; 15126/ H3, 1 female, 27.iii.2014, Kudmura, Korba District, Chhattisgarh, India, coll. E.E. Jehamalar \& party; 15127/ H3 \& 15128/H3, 2 female, 13.vi.2012, Sihawal Sagar, Achanakmar WLS, Bilaspur District, Chhattisgarh, India, coll. A. Raha \& party; 15129/H3, 1 male, 12.v.2013, Khirki, Guru Ghasidas NP, Koriya District, Chhattisgarh, India, coll. A. Raha \& party; 15130/H3 \& 15131/H3, 2 female, 15.v.2013, Kundraghat, Tamor Pingla WLS, Balrampur District, Chhattisgarh, India, coll. A. Raha \& party.

Diagnosis: Female: Clypeus smooth, strongly convex, flattened in middle, its anterior margin transversely truncate at apex; frons closely and strongly punctured; propodeal dorsum strongly punctured except at dorsolateral angle with scattered punctures; pronotum with distinct pretegular carina; fore wing with prestigma 


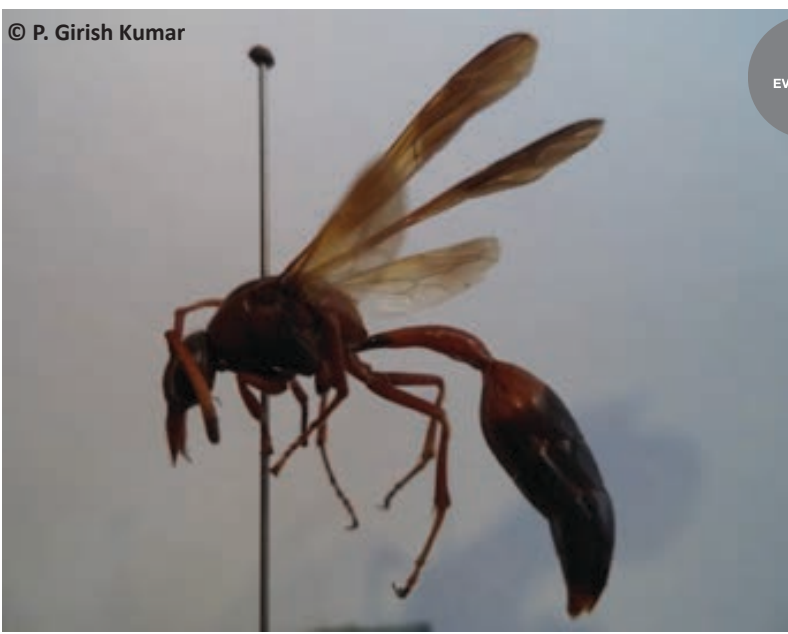

Image 24. Delta dimidiatipenne (de Saussure) Female.

$0.74 x$ pterostigma; petiole and gaster almost smooth; $\mathrm{T} 2$ without lamellae separated by apical thickening.

Colour description: Head yellow to brownish-yellow with following black markings: a broad band on vertex including upper half of frons extending behind vertex to outer side of temple and to occiput, a black mark on anterior tentorial pit extending to subantennal suture to dorsal side of antennal scrobe and touches to the black band on frons and vertex; antennae light reddish; visible part of labrum concolorous with the clypeus; mandible yellow except at margins yellowish-brown; pronotum almost entirely yellow except at anterior apex of anterior face of pronotum black; mesoscutum black except a large brown area posteriorly; scutellum light red; postscutellum yellow, propleuron black or blackishbrown; mesopleuron yellow to brownish-yellow except mesepimeron brown to blackish-brown and mesosternum black; metapleuron light red to reddishbrown; propodeum light red except at basolateral apex near to lateral corner with yellow markings; legs light reddish with highly variable yellow markings; petiole light reddish except at base black, at subapically a black band and then a yellow band; second gastral tergite basally light reddish then a black band and remaining apical half yellow; second gastral sternite light red except at apex with a yellow band; all remaining visible part of gastral segments yellow, with their bases (when drown out) black. Wings flavohyaline with a narrow subapical dark infumation on forewing.

Size $(\mathrm{H}+\mathrm{M}+\mathrm{T} 1+\mathrm{T} 2)$ : $14-20 \mathrm{~mm}$.

Male: Last antennal article hooked apically, hook long, curved and pointed, in curved position it almost reaches the apex of ninth antennal segment; S7 with a deep median longitudinal groove; apical tip of aedeagus bulb-like; parameral spine elongate with moderately large hairs subapically. Other characters almost same as in the female.

Size $(\mathrm{H}+\mathrm{M}+\mathrm{T} 1+\mathrm{T} 2):$ 14-17 $\mathrm{mm}$.

Distribution: India: Andhra Pradesh, Arunachal Pradesh, Chhattisgarh, Delhi, Gujarat, Himachal Pradesh, Jharkhand, Karnataka, Kerala, Maharashtra, Manipur, Meghalaya, Odisha, Rajasthan, Tamil Nadu, Uttarakhand, Uttar Pradesh, West Bengal. Elsewhere: Arabia, Australia, Indonesia (Borneo, Java), Iran, Iraq, Laos, Mauritius, Myanmar, Pakistan, Philippines, Sri Lanka, Thailand, Timor.

Remarks: Kumar (2012b) previously recorded this species from Kukrel (Dhamtari district), Sonpur \& Chitrakoot (Bastar district) of Chhattisgarh.

\section{Delta pyriforme pyriforme (Fabricius, 1775) (Image 26)}

Vespa pyriformis Fabricius, 1775: 371. Type: China (?).

Delta pyriforme pyriforme; Krombein, 1991: 8.

Material examined: 13151/H3, 1 female, 14.xii.1981, Chitrakoot, Bastar District, Chhattisgarh, India, coll. M.S. Shishodia \& party; 14518/H3, 1 female, 3.vii.2011, Tinsa Pathar, Barnawapara WLS, Raipur District, Chhattisgarh, India, coll. Kailash Chandra \& party; 14519/H3, 1 female, 6.vii.2011, Nawapara, Raipur District, Chhattisgarh, India, coll. S.K. Gupta \& party; 14520/H3, 1 female, 14.vii.2011, Lalbandha pond side, Raipur District, Chhattisgarh, India, coll. S.K. Gupta \& party; 14521/H3 \& 14522/H3, 2 female, 3.viii.2011, Ramgarh, Koriya District, Chhattisgarh, India, coll. A. Raha \& party; 14523/H3, 1 male, 16.xi.2011, Kherpani forest, Kabirdham District, Chhattisgarh, India, coll. S.K. Gupta \& party; 14524/H3, 1 female, 25.v.2012, 
Barband, Badalkhol, Jashpur District, Chhattisgarh, India, coll. A. Raha \& party; $14525 /$ H3 \& 14526/H3, 1 female \& 1 male, 11.i.2013, Bacheli, Dandewada District, Chhattisgarh, India, coll. P. Girish Kumar; 14527/H3 \& 14528/H3, 2 female, 12-13.i.2013, Kirandul, Dandewada district, Chhattisgarh, India, coll. P. Girish Kumar; 15098/ H3, 1 female, 24.xii.2011, Pakrid, Barnawapara WLS, Raipur District, Chhattisgarh, India, coll. S.K. Gupta \& party; 15099/H3, 1 female, 19.ii.2012, Sarangarh, Gomardo WLS, Raipur District, Chhattisgarh, India, coll. S.K. Gupta \& party; 15100/H3, 1 female, 9.x.2011, Sunhat, Koriya District, Chhattisgarh, India, coll. Mandal \& party; 15101/H3, 1 female, 29.xi.2011, Duldula forest, Boramdeo WLS, Kabirdham District, Chhattisgarh, India, coll. A. Raha \& party; 15102/H3 \& 15103/H3, 2 female, 26-28.iii.2012, Jhiragaon, Jagadalpur, Bastar District, Chhattisgarh, India, coll. R.P. Gupta \& party;15104/H3, 1 female, 29.iii.2012, Hatguda, Jagadalpur, Bastar District, Chhattisgarh, India, coll. R.P. Gupta \& party; 15105/H3, 1 female, 24.xii.2011, Dashapal, Jagadalpur, Bastar District, Chhattisgarh, India, coll. R.P. Gupta \& party; 15106/H3, 1 female, 6.iv.2012, Gariyabahar Nala, Jagadalpur, Bastar District, Chhattisgarh, India, coll. R.P. Gupta \& party; 15107/H3 to 15111/H3, 2 female \& 3 male, 11.v.2013, Jalpani, Guru Ghasidas NP, Koriya District, Chhattisgarh, India, coll. A. Raha \& party; 15112/H3, 1 male, 12.v.2013, Khirki, Guru Ghasidas NP, Koriya District, Chhattisgarh, India, coll. A. Raha \& party; 15113/H3 \& 15114/H3, 2 female, 14.v.2013, Pingla Nala, Tamor Pingla WLS, Balrampur District, Chhattisgarh, India, coll. A. Raha \& party.

Diagnosis: Female: Clypeus smooth, strongly convex, flattened in middle, its anterior margin concave at apex, frons closely and strongly punctured; upper part of propodeum strongly punctured except at dorsolateral angle smooth; fore wing with prestigma 1.11x pterostigma; gaster almost smooth with minute scattered punctures; T2 without lamellae separated by apical thickening.

Colour description: Head yellow, a broad transverse black band between the eyes on the vertex through ocellar area; occiput mostly black; antenna reddishbrown; Pronotum entirely and mesoscutum anteriorly yellow, the later posteriorly black or brown or reddishbrown; tegula reddish-brown; parategula reddishbrown; scutellum and postscutellum usually reddishbrown with highly variable black markings; propleuron black; mesopleuron, metapleuron, propodeum and legs reddish-brown with highly variegated black markings; the sutures between the scutellum, postscutellum and propodeum black; petiole and basal third of the second gastral segment reddish-brown, the former black at base and with a subapical black band, the middle of the later black, its posterior third and the visible part of the remaining abdominal segments yellow. Wings deep flavohyaline with a narrow infumation on the apical margin of forewing.

Size $(\mathrm{H}+\mathrm{M}+\mathrm{T} 1+\mathrm{T} 2):$ 25-27 mm.

Male: Last antennal article hooked apically, hook long, curved and pointed, the terminal half distinctly swollen in profile and widened seen from above, in curved position it almost reaches the apex of ninth antennal segment; S3-S6 with few large hairs apically; S7 with a deep median longitudinal groove; apical tip of aedeagus bulb-like; parameral spine elongate with moderately large hairs sub apically; volsella with moderately large thick hairs. The male comparatively smaller and slighter than the female. Other characters almost same as that of the female.

Size $(\mathrm{H}+\mathrm{M}+\mathrm{T} 1+\mathrm{T} 2):$ 18-23 $\mathrm{mm}$.

Distribution: India: Andaman \& Nicobar Islands, AndhraPradesh, Arunachal Pradesh, Assam, Chhattisgarh, Delhi, Gujarat, Himachal Pradesh, Jharkhand, Karnataka, Kerala, Maharashtra, Manipur, Meghalaya, Mizoram, Nagaland, Odisha, Pondicherry, Rajasthan, Sikkim, Tamil Nadu, Tripura, Uttarakhand, Uttar Pradesh, West Bengal. Elsewhere: Bhutan, Cambodia, China, Hawaii, Hong Kong, Indonesia, Malaysia, Moluccas, Myanmar, Nepal, New Guinea, Pakistan, Sri Lanka, Taiwan, Thailand, Vietnam.

Remarks: Kumar \& Kishore (2012) previously recorded this species from Chitrakoot in Bastar district of Chhattisgarh.

\section{Genus Indodynerus Gusenleitner}

Indodynerus Gusenleitner, 2008: 1495, 1500, genus. Type species: Indodynerus capitatus Gusenleitner, 2008, by monotypy and original designation.

This genus is endemic to the Indian subcontinent with only one species namely Indodynerus capitatus Gusenleitner, 2008.

\section{Indodynerus capitatus Gusenleitner, 2008 (Image 27)}

Indodynerus capitatus Gusenleitner, 2008: 1500, 1501. Holotype: Female, Karnataka: Sulyamedikeri (OLM).

Material examined: 13852/H3, 1 female, 18.x.2011, Taurenga, Gariaband District, Chhattisgarh, India, coll. S.K. Gupta \& party; 15280/H3, 1 female, 2.x.2013, Balod, Durg District, Chhattisgarh, India, coll. A. Raha \& party.

Diagnosis: Female: Clypeus with very fine sparse 

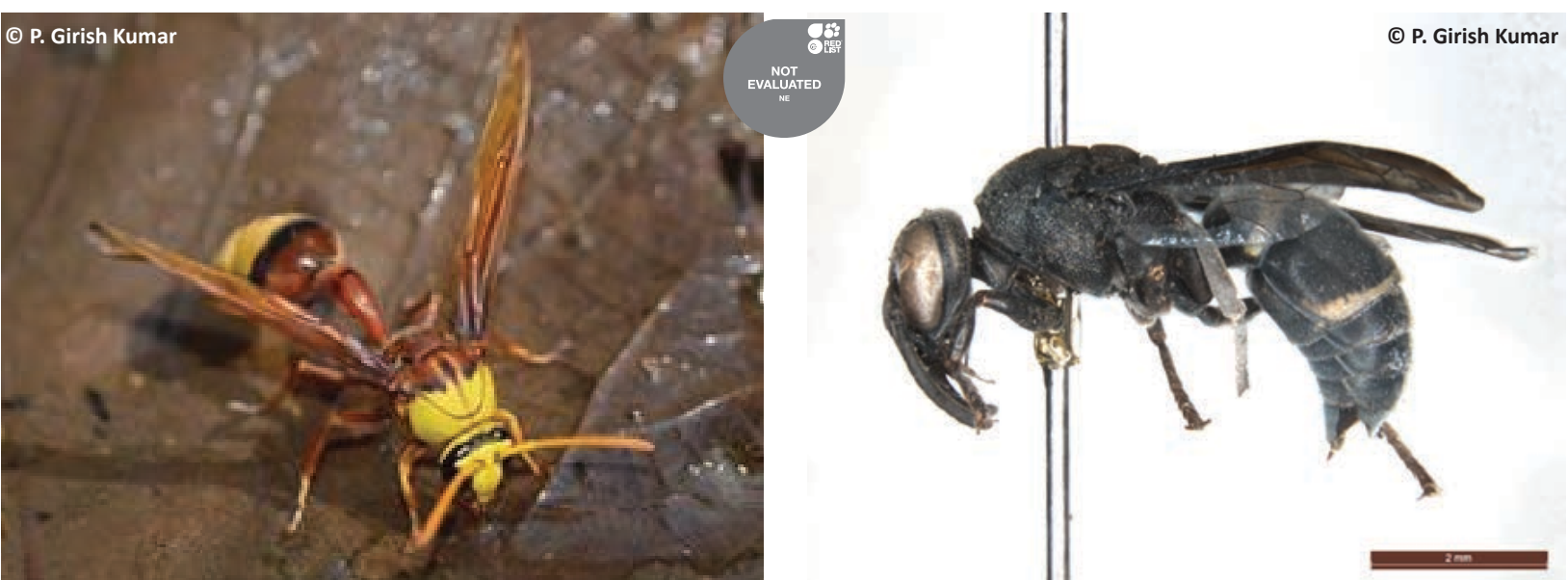

Image 26. Delta pyriforme pyriforme (Fabricius) Female.

Image 27. Indodynerus capitatus Gusenleitner Female.

punctures; epicnemial carina absent.

Colour description: Body black with the following white parts: a transverse band at base of clypeus, a thick band at inner margin of eye starting from base of clypeus up to ocular sinus, a spot at interantennal space, a mark on the upper portion of temple, a transverse band at middle of pronotum; T1 with a broad and T2 with a narrow transverse band at apex; S2 with a small spot on postero-lateral corner. Mandible, tarsal spines and claws blackish-brown. Wings dark with violaceous reflections.

Size $(\mathrm{H}+\mathrm{M}+\mathrm{T} 1+\mathrm{T} 2): 11 \mathrm{~mm}$.

Distribution: India: Chhattisgarh, Karnataka, Kerala. Elsewhere: Pakistan.

Remarks: Kumar et al. (2013) previously recorded this species from Taurenga in Gariaband district of Chhattisgarh.

\section{Genus Oreumenoides Giordani Soika}

Oreumenoides Giordani Soika, 1961: 245, genus. Type species Eumenes edwardsii de Saussure, 1852, by original designation and monotypy.

This genus is endemic to the South and SouthEast Asia with only one species namely Oreumenoides edwardsii (de Saussure, 1852).

\section{Oreumenoides edwardsii (de Saussure, 1852)} (Image 28)

Eumenes edwardsii de Saussure, 1852: 60. Syntype: Female, Les Indes-Orientales, Bombay (MP).

Oreumenoides edwardsii; Giordani Soika, 1961: 245.

Material examined: 14532/H3, 1 male, 25.v.2012, Bardand, Badalkhol, Jashpur District, Chhattisgarh, India, coll. A. Raha \& party; 14533/H3, 1 male, 26.v.2012, Manda Tengna, Badalkhol, Jashpur District, Chhattisgarh, India, coll. A. Raha \& party; 14532/H3, 1 male, 28.v.2012,
Bhutunga Nala, Badalkhol, Jashpur District, coll. A. Raha \& party.

Diagnosis: Male: Apical antennal article minute, not coiled apically; parameral spine with moderately large hairs.

Colour description: Body ferruginous red with yellow and black markings. Yellow markings as follows: at the clypeus, a triangular mark on interantennal space, inner margin of lower eye extends up to ocular sinus, a narrow line on outer margin of eye, a spot on ventral side of antennal attachment, a short line on middle of the pronotum, a spot on tegula apically, parategula, lower half of metanotum, a small spot on antero-lateral side of propodeum, a small spot on postero-lateral corner of propodeum, propodeal valvula, a streak on outer side oftibiae and basitarsi, a yellow mark on the outer side offore, mid and hind femora, a streak on each side just after middle of petiole, two subapical spots and two spots on postero-lateral corner on the same above, two lateral oval spots basally and a broad band apically on T2, two spots postero-laterally on T3, a narrow band on S2 apically, a broad band on S3 and S4 apically (sometimes fifth and sixth also). Black markings as follows: frons except inner ocular sinus, vertex, temple except ocular margin of eye, occiput, mesoscutum except anMshaped ferruginous brown marking, apical margin of scutellum, basal half of metanotum, axillary fossa, suture between metanotum and propodeum, median groove of propodeum, mesepimeron largely, ventral side of mesosoma, base and middle of petiole above, middle of second gastral tergite, a broad longitudinal band from base up to middle of S2, two lateral spots on S2 subapically (sometimes faint, appears to be blackishbrown). Forewing almost hyaline with some brown infumation anteriorly, a distinct brown infumation on 
radial cell at distal half;

Size $(\mathrm{H}+\mathrm{M}+\mathrm{T} 1+\mathrm{T} 2):$ 14-16 mm.

Distribution: India: Chhattisgarh (new record), Delhi, Jharkhand, Karnataka, Kerala, Madhya Pradesh, Maharashtra, Pondicherry, Rajasthan, Tamil Nadu, Uttar Pradesh, West Bengal. Elsewhere: Myanmar, Nepal, Pakistan, Thailand.

\section{Genus Pareumenes de Saussure}

Pareumenes de Saussure, 1855: 133. Type species Eumenes quadrispinosus de Saussure, 1855, by subsequent designation of Bequaert, 1918: 271.

Genus Pareumenes de Saussure consists of two subgenera namely Nortonia de Saussure and Pareumenes de Saussure of which the subgenus Pareumenes consists of six species and an additional four subspecies from the oriental Region. Three species and an additional one subspecies are reported from India and Chhattisgarh having only one species namely Pareumenes brevirostratus (de Saussure, 1855).

\section{Pareumenes brevirostratus (de Saussure, 1855)} (Image 29)

Eumenes brevirostratus de Saussure, 1855: 136. Type: "Les Indes Orientales", from F. Smith (? BMNH) (in division Pareumenes).

Pareumenes brevirostratus; Dalla Torre, 1904: 19 (brevirostrata; cat.).

Material examined: 14542/H3, 1 female, 16.x.2011, Thatajhiria, Dhamtari District, Chhattisgarh, India, coll. S.K. Gupta \& party.

Diagnosis: Female: Clypeus with two projecting teeth at apex; metanotum subangular posteriorly; petiole broad at apex.
Colour description: Body red; head yellow except for the occiput and a transverse band across the vertex enclosing the eye; a broad yellow band on pronotum; posterior half of $\mathrm{T} 2$ and the following tergites are yellow. Wings flavohyaline.

Size $(\mathrm{H}+\mathrm{M}+\mathrm{T} 1+\mathrm{T} 2): 17 \mathrm{~mm}$.

Distribution: India: Chhattisgarh (new record), Karnataka, Kerala, Maharashtra, Odisha, Sikkim, Tamil Nadu, Uttar Pradesh, West Bengal.

\section{Genus Phimenes Giordani Soika}

Phimenes Giordani Soika, 1992: 41, 66. Type species Vespa arcuata Fabricius, 1775, by subsequent designation of Bequaert, 1926: 487, as type species of Phi de Saussure, 1855.

The genus Phimenes Giordani Soika is widely distributed in the Australian and Oriental region. At present, 19 species with an additional 38 subspecies are recorded from the world. The species Phimenes flavopictum (Blanchard, 1845) is the only species distributed in mainland India.

\section{Phimenes flavopictum (Blanchard, 1840) (Image 30)}

Eumenes flavopictus Blanchard, 1840, in Ch. d’Orbigny, vol. 2, Ins., Hym., pl. 2, fig. 21, Type locality Unknown (?MP).

Phimenes flavopictum; Kumar, 2013a: 120.

Material examined: 14535/H3 \& 14536/H3, 2 female, 2.xi.2011, Bhimbhori Nala, Barnawapara WLS, Raipur District, Chhattisgarh, India, coll. S.K. Gupta \& party; 14537/H3 \& 14538/H3, 1 female \& 1 male, 7.xi.2011, near Parbatiya waterfalls, Barnawapara WLS, Raipur District, Chhattisgarh, India, coll. A.K. Sarsavan \& party; 14539/H3, 1 female, 22.xi.2011, Jamunpani

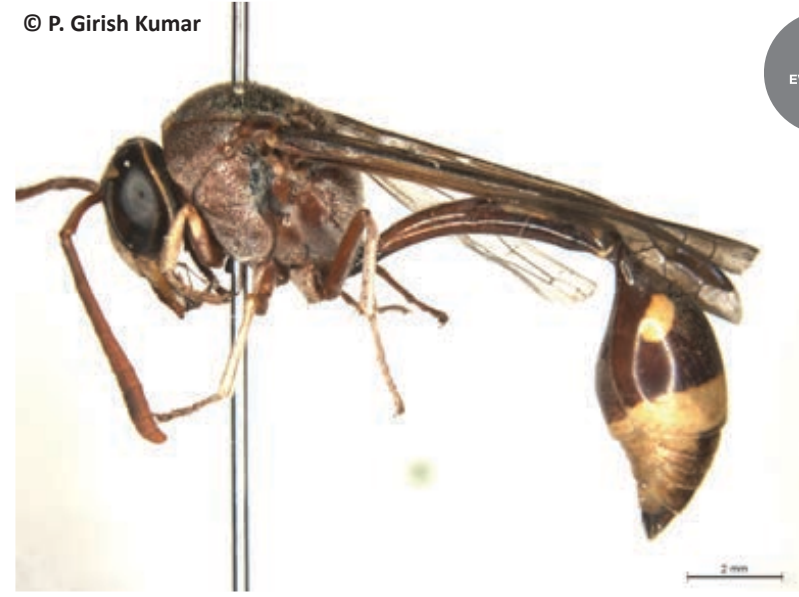

Image 28. Oreumenoides edwardsii (de Saussure) Male.

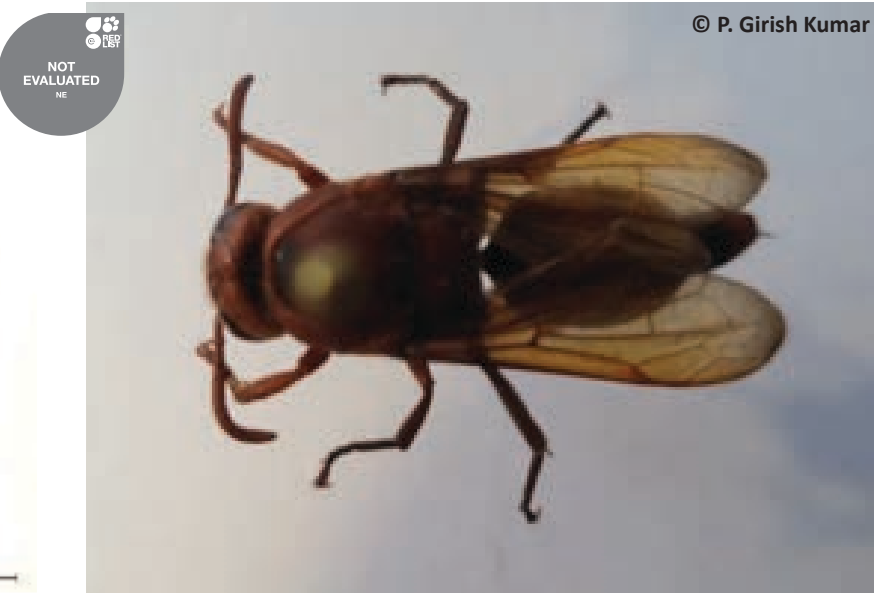

Image 29. Pareumenes brevirostratus (de Saussure) Female. 
forest, Kabirdham District, Chhattisgarh, India, coll. A.K. Sarsavan \& party; 15132/H3, 1 female, 30.ix.2011, Dheba, Barnawapara WLS, Raipur District, Chhattisgarh, India, coll. S.K. Gupta \& party; 15133/H3, 1 female, 20.xi.2011, Loop forest, Boramdeo WLS, Kabirdham District, Chhattisgarh, India, coll. A.K. Sarsavan \& party; 15134/H3 \& 15135/H3, 2 male, 24.xi.2011, Baudha forest, Boramdeo WLS, Kabirdham District, Chhattisgarh, India, coll. A.K. Sarsavan \& party; 15136/H3, 2 male, 29.xi.2011, Duldula forest, Boramdeo WLS, Kabirdham District, Chhattisgarh, India, coll. A. Raha \& party.

Diagnosis: Female: Apex of clypeuswidely truncate, anterior margin moderately emarginate, sparsely punctate; frons closely and strongly punctured; propodeal dorsum strongly punctured except at dorsolateral angle almost smooth; pronotum with distinct pretegular carina; fore wing with prestigma 1.31x pterostigma; petiole and gaster almost smooth; T2 without lamellae separated by apical thickening, slightly curved inwards medially at apex.

Colour description: Black with the following yellow markings: clypeus, an inter antennal mark, a line at the inner orbits, a narrow line at the outer orbits; a transverse band on the pronotum; four spots on the mesoscutum, a small mark on the lateral areas of the scutellum, marks behind axillary fossa near base of hind wing, a vertical band on the mesepisternum, a band on outer margin of tegulae, a band on the postscutellum, two large marks on posterior area of propodeum; marks on outer side of mid and hind coxae, a line at the inner side of fore femora, most of the fore tibiae (leaving a brown line on the inner side), a line on the outer side of mid and hind tibiae; three pairs of spots on the gastral petiole; a pair of transverse spots at the base of T2, forming an interrupted band, narrowly interrupted bands at the apex of T2-T5, a pair of small spot at apex of T6 and widely interrupted bands at the apex of S2S5. Brown markings as follows: labrum brown; mandible blackish-brown. Wings fusco-hyaline.

Size (H+M+T1+T2): 24-26 mm.

Male: Apical antennal article hooked apically, hook long, curved and pointed, in curved position it almost reaches the apex of ninth antennal segment; S3-S6 with dense hairs; S7 almost flat, rounded apically without dense hairs except at apical margin, apical margin with dense hairs; apical tip of aedeagus bulb-like; pubescence of base of volsella long and dense; digitus of volsella wider, densely pubescent at base, dorsally with distinct blunt angle; parameral spine elongate with moderately large hairs. Other characters almost the same as in the female.

Size $(\mathrm{H}+\mathrm{M}+\mathrm{T} 1+\mathrm{T} 2): 18 \mathrm{~mm}$.

Distribution: India: Arunachal Pradesh, Assam, Chhattisgarh (new record), Delhi, Jharkhand, Karnataka, Kerala, Maharashtra, Manipur, Meghalaya, Mizoram, Nagaland, Sikkim, Tamil Nadu, Tripura, Uttarakhand, West Bengal. Elsewhere: China, Hong Kong, Indonesia, Malaysia, Myanmar, Singapore, Sri Lanka, Thailand.

\section{Genus Rhynchium Spinola}

Rhynchium Spinola, 1806: 84. Type species Rygchium europeaum Spinola, 1806 [= Vespa oculata Fabricius, 1781], by monotypy.

The genus Rhynchium Spinola is distributed in the Australian, Ethiopian, Oriental and Palearctic regions of the world. Forty seven species with several subspecies are recorded under this genus worldwide of which four species with an additional two subspecies namely Rhynchium brunneum brunneum (Fabricius, 1793), R. brunneum ceylonicum Giordani Soika, 1994, R. carnaticum (Fabricius, 1798), R. haemorrhoidale haemorrhoidale (Fabricius, 1775), R. haemorrhoidale andamanicum Kumar \& Sharma, 2013 and R. oculatum leviscutis (Cameron, 1908) are recorded from the Indian subcontinent (Kumar \& Sharma, 2013). Only two species namely $R$. brunneum brunneum and $R$. carnaticum were reported from Chhattisgarh.

\section{Rhynchium brunneum brunneum (Fabricius, 1793) (Image 31)}

Vespa brunnea Fabricius, 1793: 264. Syntype: sex not mentioned, "Tranquebariae, India (HMUG)".

Rhynchium brunneum; Spinola, 1808: 189.

Material examined: 13850/H3, 1 female, 20.x.2011, Sankra forest, Sitanadi WLS, Dhamtari District, Chhattisgarh, India, coll. S.K. Gupta \& party.

Diagnosis: Female: Clypeus strongly convex, pyriform, the apical third with a broad medial vertical groove, the extreme apex truncate, apex of truncated portion slightly incised, with moderately deep punctures, larger

Key to species/subspecies of Rhynchium Spinola occurring in Chhattisgarh

1. Clypeus, in both sexes, with punctures extremely small and superficial; punctures on T1 and basal 2/3 of remaining tergites, in both sexes, small, shallow and sparse ........................................................................................................ carnaticum (Fabricius)

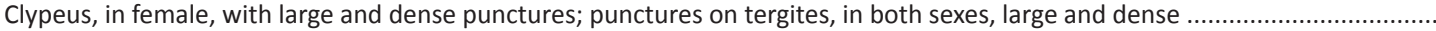

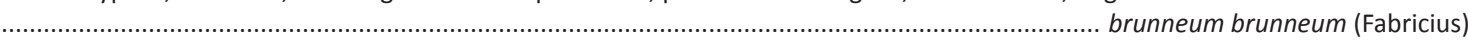




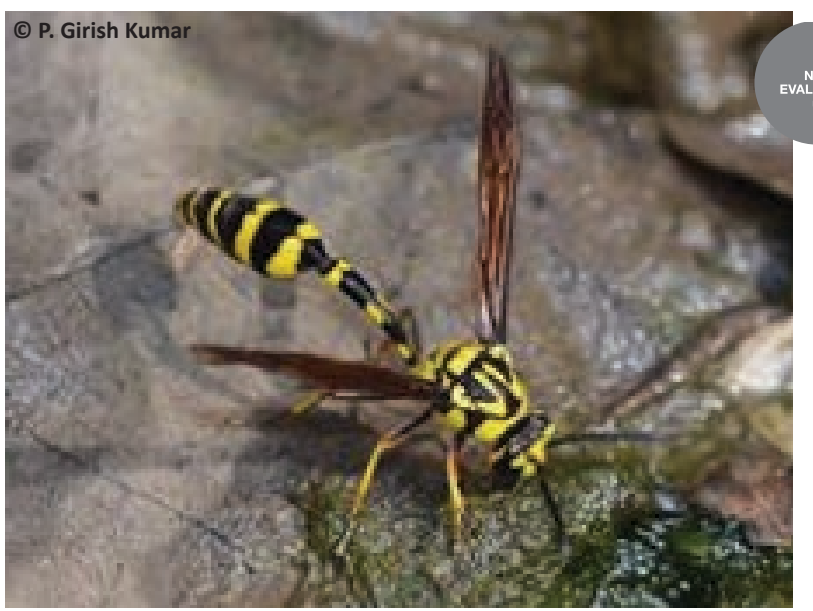

Image 30. Phimenes flavopictum (Blanchard) Female.

punctures on middle and smaller on sides.

Colour description: Body brownish-red (and sometimes mixed with yellowish-red) with the following black marks: a spot on interantennal space, a vertical line on lower frons, around ocelli, occiput, a large triangular mark on mesoscutum in front, a transverse line along its apex, propleuron, mesopleuron (except brownish-red below tegula), metapleuron, propodeum in the middle and lateral sides below, basal two thirds of the T1 and the basal half of T2, S1 and S2 almost entirely, base of S3. Legs brownish-red with variegated black markings. The black markings in the body are highly variable. Wings yellowish hyaline, deeper and darker towards base; veins yellow, brown towards base; apical margin of forewing slightly infumated.

Size $(H+M+T 1+T 2): 15 \mathrm{~mm}$.

Distribution: India: Arunachal Pradesh, Bihar, Chhattisgarh, Jharkhand, Maharashtra, Meghalaya, Odisha, Sikkim, Tamil Nadu, Tripura, Uttarakhand, West Bengal. Elsewhere: Afghanistan, Cambodia, China, Guam, Indonesia, Iran, Iraq, Malaysia, Marquesas Island, Myanmar, Nepal, New Britain, Pakistan, Society Islands, Taiwan, Thailand.

Remarks: Kumar \& Sharma (2013) reported this species from Sankra forest (Sitanadi Wildlife Sanctuary: Dhamtari district) of Chhattisgarh.

32. Rhynchium carnaticum (Fabricius, 1798) (Image 32)

Vespa carnatica Fabricius, 1798: 261. Syntype, sex not mentioned, Tranquebariae (ZMUC).

Rhynchium carnaticum; de Saussure, 1852: 112.

Material examined: 15274/H3, 1 female, 30.v.2012, Kudmura, Korba District, Chhattisgarh, India, coll. A. Raha \& party; 15275/H3 \& 15276/H3, 2 female, 15.v.2013, Kudraghat, Tamor Pingla WLS, Balrampur

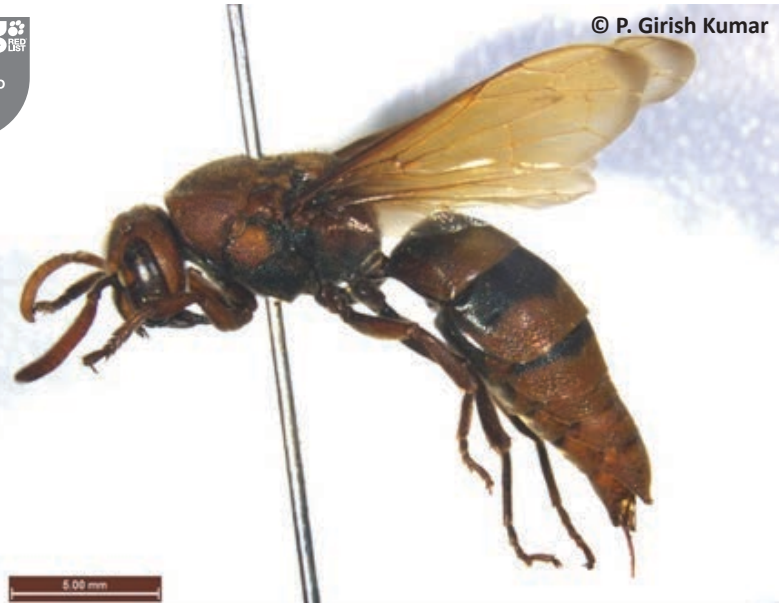

Image 31. Rhynchium brunneum brunneum (Fabricius) Female.

District, Chhattisgarh, India, coll. A. Raha \& party.

Diagnosis: Female: Mesoscutum posteriorly and scutellum almost impunctate with few sparse punctures on posterior sides; metanotum somewhat compressed medially; T2-T5 with very minute sparse and shiny punctures on $3 / 4$ area and S2-S4 with distinct punctures, the diameter of most of the punctures less than interspace.

Colour description: Body brownish-red with the following black marks: a spot on interantennal space, a vertical line on lower frons, around ocelli, occiput, a triangular mark on mesoscutum in front, a transverse line along its apex, lateral sides of propleuron, epicnemium, propodeum in the middle, basal area of T1, at the base of T2, in between S1 and S2, base of S3. Legs brownishred with variegated black markings. Wings yellowish hyaline, deeper and darker towards base; apical margin of forewing slightly infumated.

Size $(\mathrm{H}+\mathrm{M}+\mathrm{T} 1+\mathrm{T} 2): 14.5 \mathrm{~mm}$.

Distribution: India: Andhra Pradesh, Assam, Bihar, Chhattisgarh (new record), Delhi, Himachal Pradesh, Jharkhand, Karnataka, Madhya Pradesh, Meghalaya, Odisha, Rajasthan, Tamil Nadu, Uttarakhand, West Bengal. Elsewhere: Indonesia, Pakistan, Sri Lanka.

\section{Genus Xenorhynchium van der Vecht}

Xenorhynchium Vecht, 1963:111. Type species Vespa nitidula Fabricius, 1798, by original designation and monotypy.

This genus is endemic to the Indian subcontinent with only one species namely Xenorhynchium nitidulum (Fabricius, 1798). 


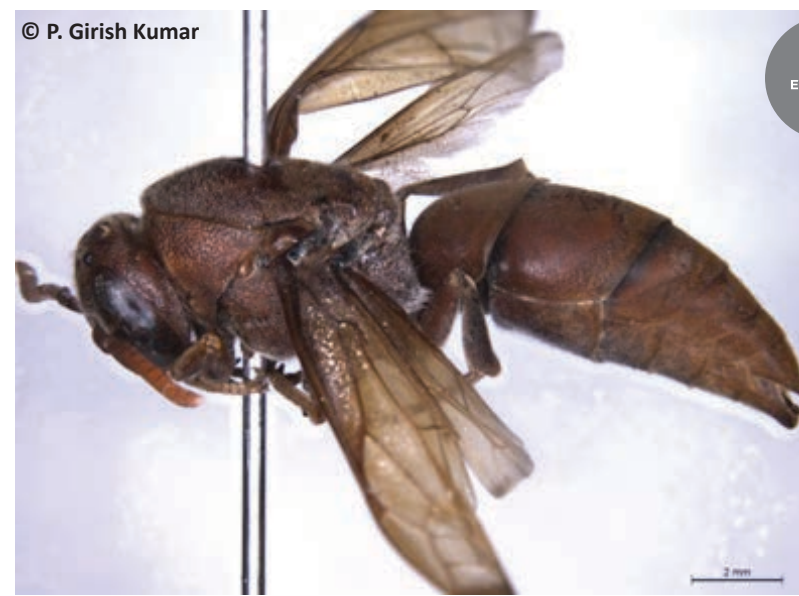

Image 32. Rhynchium carnaticum (Fabricius) Female.

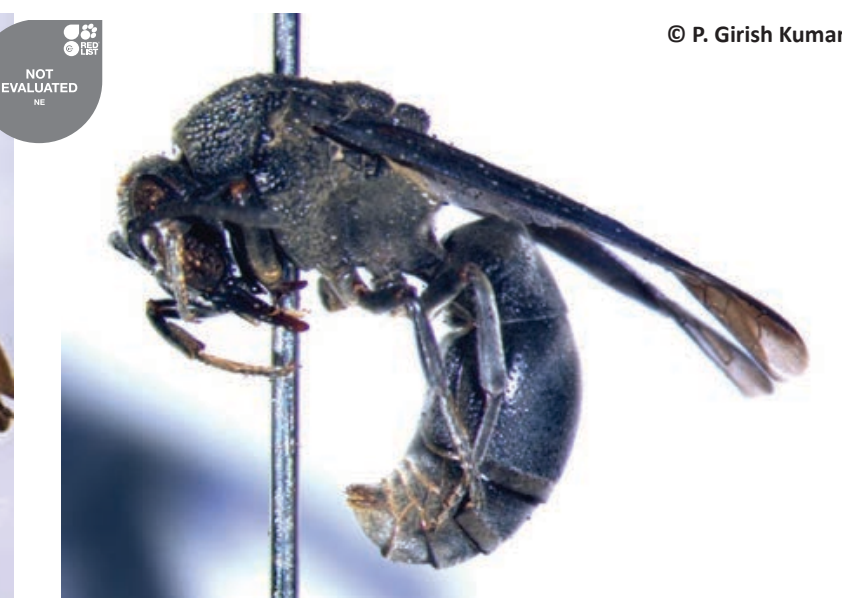

Image 33. Xenorhynchium nitidulum (Fabricius) Female.

\section{Xenorhynchium nitidulum (Fabricius, 1798) (Image} 33)

Vespa nitidula Fabricius, 1798: 262, Syntype: India Orientalis (ZMUK).

Xenorhynchium nitidulum; Vecht, 1963: 111.

Material examined: 14540/H3, 1 male, 26.v.2012, Manda Tegna, Badalkhol, Jashpur District, Chhattisgarh; India, coll. A. Raha \& party; 14541/H3, 1 female, 27.v.2012, Pakhridhab, Badalkhol, Jashpur District, coll. A. Raha \& party; 15277/H3, 1 female, 16.x.2011, Sankra forest, Sitanadi WLS, Dhamtari District, coll. S.K. Gupta \& party; 15278/H3, 1 female, 11.v.2013, Jalpani, Guru Ghasidas NP, Koriya District, coll. A. Raha \& party; 15279/ H3, 1 female, 15.v.2013, Kundraghat, Tamor Pingla WLS, Balrampur District, coll. A. Raha \& party.

Diagnosis: Female: clypeus pyriform, bisinuate at apical half, apex broadly emarginate and angularly incised, sides on either side of apex oblique; labrum triangularly pointed at apex; tegula enlarged laterally, exceeding parategula posteriorly; postscutellum strongly raised above the level of adjoining areas of propodeum, the flattened dorsal surface approximately rectangular and about as long as the vertically sloping posterior surface; propodeum with prominent lateral angles, the concave declivity rather sharply separated from dorsal and lateral areas.

Colour description: Body black with lower part of ocular sinus brown; wings deep fuscous with a purple reflection broadly along costal margin of forewing, the rest fusco-hyaline.

Size $(\mathrm{H}+\mathrm{M}+\mathrm{T} 1+\mathrm{T} 2): 14 \mathrm{~mm}$.

Male: Antennal hook long and curved, somewhat dilated and flattened in apical half, with rounded apex, in curved position it almost reaches the apex of ninth antennal segment; S7 rather strongly excavated, the concave area finely, granulately punctate and bordered by an arcuate and blunt ridge; parameral spine elongate. Other characters almost as in the female.

Colour description: Same as that of the female except base of clypeus and ventral side of scape whitishyellow, all flagellar segments brown ventrally, lower part of ocular sinus brown.

Size (H+M+T1+T2): 14mm.

Distribution: India: Andhra Pradesh, Bihar, Chhattisgarh (new record), Gujarat, Himachal Pradesh, Jammu \& Kashmir, Jharkhand, Karnataka, Kerala, Maharashtra, Odisha, Pondicherry, Rajasthan, Tamil Nadu, Uttarakhand, Uttar Pradesh, West Bengal. Elsewhere: Pakistan.

\section{REFERENCES}

Ashmead, W. H. (1904). Description of a new genera and species of Hymenoptera from the Philippine Islands. Proceedings of the United States National Museum 28: 127-158. http://dx.doi.org/10.5479/ si.00963801.28-1387.127.

Bequaert, J. C. (1918). A revision of the Vespidae of the Belgian Congo based on the collection of the American Museum Congo Expedition, with a list of Ethiopian diplopterous wasps. Bulletin of the American Museum of Natural History 39: 1-384.

Bequaert, J. (1925). Eumenes dyscherus, a Neotropical, not an African wasp, and other notes on synonymy (Hymenoptera). Bulletin of the Brooklyn Entomological Society 20(3): 134-140.

Bequaert, J.C. (1926). The genus Eumenes Latrielle in South Africa with a revision of the Ethiopian species (Hymenoptera). Annals of the South African Museum 23: 483-576.

Bequaert, J. (1936). The common Oriental hornets, Vespa tropica and Vespa affinis and their color forms. Treubia 15(4): 329-351.

Bequaert, J. (1940). Notes on Oriental Polistes wasps (Hymenoptera, Vespidae). Transactions of the American Entomological Society 66: 265-272.

Bingham, C.T. (1897). The Fauna of British India, including Ceylon and Burma. Hymenoptera, I. Wasps and Bees: 579+ i- xxix. Taylor and Francis, London.

Blanchard, E. (1840). Classe des Insectes. In : d'Orbigny, C., Dictionnaire 
universel d'Histoire naturelle. Atlas, Tome II, Zoologie. Abel, Pilon et Cie, Éditeurs, Paris, pp. 9-22.

Blüthgen, P. (1961). Ergebnisse der Deutschen Afghanistan-Expedition 1956 der Landessammlungen für Naturkunde Karlsruhe. Beiträge zur Naturkundlichen Forschung in Südwestdeutschland 19: 277-287.

Buysson, R. du. (1908). Deux Hyménoptè res nouveaux de Java.Notes from the Leiden Museum 30: 123-126.

Cameron, P. (1900). Descriptions of new genera and species of Hymenoptera. Annals and Magazine of Natural History (7)6: 410-419, 495-506, 530-539. http://dx.doi. org/10.1080/00222930008678415

Cameron, P. (1903). Description of nineteen new species of Larridae Odynerus and Apidae from Barrackpore. Transactions of the Entomological Society of London Vol. 1903: 117-132.

Carpenter, J.M. (1996). Distributional checklist of the species of the genus Polistes (Hymenoptera: Vespidae; Polistinae, Polistini) American Museum Novitates 3188: 1-39.

Carpenter, J.M. \& L.P.T. Nguyen (2003). Keys to the genera of social wasps of South-East Asia (Hymenoptera: Vespidae). Entomologica Science 6: 183-192.

Dalla Torre, K.W. (1904). Vespidae, Genera Insectorum 19: 1-108.

Das, B.P. \& V.K. Gupta (1983). A catalogue of the families Stenogastridae and Vespidae from the Indian Subregion (Hymenoptera: Vespoidea) Oriental Insects 17: 395-464.

Das, B.P. \& V.K. Gupta (1989). The social wasps of India and the adjacent countries (Hymenoptera: Vespidae). Oriental Insects Monograph 11: 1-292.

De Geer, C. (1773). Mèmoires pour Servir à l'Histoire des Insectes. Tome troisiéme. P. Hesselberge, viii +696 pp. +44 pls.

Dover, C. \& H.S. Rao (1922). A note on the Diplopterous Wasps in the Collection of the Indian Museum. Journal of Asiatic Society of Bengal [N.S. XVIII]: 235-249.

Fabricius, J.C.F. (1775). Systema Entomolgiae, etc. xxviii + 832 pp. Kortii, Flensburgi et Lipsiae.

Fabricius, J.C.F. (1787). Mantissa Insectorum, Sistens Species nuper detectas, 1, Hafniae I-XX+1-384

Fabricius, J.C.F. (1793). Entomologia Systematica Emendate et acuta. Secundum, Classes, Ordines, Genera, Species, Adiectis Synonymis, Locis, Observationibus, Descriptionibus 2. Hafniae, viii+519pp.

Fabricius, J.C.F. (1798). Supplementum entomologiae systematicae. [2]+572 pp. Hafniae.

Fabricius, J.C.F. (1804). Systema Piezatorum Secundum, Ordines, Genera, Species, Adiectis Synonymis, Locis, Observationibus, Descriptionibus. Brunschweig, XIV+[15]-[440]+[1]-30pp.

Guérin-Méneville, F.C. (1831-1838). Crustacees, Arachnides et Insects. In Duperrey, L.J., "Voyage author du Monde sur la Coquille (1822 25)". Zoologie, 2(2), Div. I. Paris. 319 pages.

Gusenleitner, J. (1996). Uber Eumenidae der orientalischen Region (Hymenoptera, Vespoidea). Linzer Biologischen Beitrage 28(1) 39-56.

Gusenleitner, J. (2006). Uber Aufsammlungen von Faltenwespen in Indien (Hymenoptera, Vespidae). Linzer Biologischen Beitrage 38(1): 677-695.

Gusenleitner, J. (2008). Bemerkenswerte Faltenwespen-Funde aus der orientalischen region Teil 4. Mit einem Anhang uber eine Art aus Neu-Kaledonien (Hymenoptera, Vespidae, Eumeninae). Linzer Biologischen Beitrage 40 (2): 1495-1503.

Illiger, K. (1802). Neue Insekten. Magazin für Insektenkunde 1(1-2) 163-208.

Kirby, W.F. \& W. Spence (1828). An Introduction to Entomology. London, $5^{\text {th }}$ Edition, 4 vols.

Kishore, L. (2004). Two new species and a new subspecies of Antepipona Saussure (Hymenoptera: Vespidae) from India with a key to species. In: Perspectives on Biosystematics and Biodiversity (Eds., K. Rajmohana et al.). Prof. T. C. Narendran Com. Vol., 553-566.

Kishore, L. \& T.C. Narendran (2002). A new species of Antepipona Saussure (Hymenoptera: Vespidae) from India. Journal of Zoological Society of Kerala 10(1\&2): 1-4.

Kojima, J. \& J.M. Carpenter (1997). Catalog of species in the polistine tribe Ropalidiini (Hymenoptera: Vespidae). American Museum Novitates 3199: 1-96.

Kojima, J, L. Kishore, L.T.P. Nguyen \& F. Saito (2007). Taxonomic notes on the paper wasps of the genus Ropalidia in the Indian subcontinent (Hymenoptera: Vespidae). Entomological Science 10: 373-393.

Krombein, K. V. (1991). Biosystematic Studies of Ceylonese Wasps, xix: Natural History Notes in Several families (Hymenoptera: Eumenidae, Vespidae, Pompilidae, and Crabronidae). Smithsonian Contributions to Zoology283: 1-41.

Kumar, P.G. (2012a). On Delta dimidiatipenne (de Saussure, 1852) (Hymenoptera: Vespidae: Eumeninae) from India. Journal of Environment \& Sociobiology 9(1): 43-49.

Kumar, P.G. (2012b). Redescription and new distributional records of Delta esuriens (Fabricius) (Hymenoptera: Vespidae; Eumeninae) from Indian states. Records of Zoological Survey of India 112(Part4): 55-60.

Kumar, P.G. (2013a). A taxonomic revision of Phimenes Giordani Soika (Hymenoptera: Vespidae: Eumeninae) of Indian subcontinent. Records of Zoological Survey of India 113(Part-3): 119-135.

Kumar, P.G. (2013b). A study on the genus Anterhynchium de Saussure (Hymenoptera: Vespidae: Eumeninae) from Indian subcontinent. Records of Zoological Survey of India 113(Part-4): 139-158.

Kumar, P.G. \& J.M. Carpenter (2013). A taxonomic review of the genus Antodynerus de Saussure, 1855 (Hymenoptera: Vespidae: Eumeninae) from the Indian subcontinent. Zootaxa 3731(2): 267278. http://dx.doi.org/10.11646/zootaxa.3731.2.7

Kumar, P.G. \& G. Sharma (2013). A taxonomic study on the genus Rhynchium Spinola (Hymenoptera: Vespidae: Eumeninae) from the Indian subcontinent. Records of Zoological Survey of India 113 (Part2): 105-122.

Kumar, P.G. \& L. Kishore (2012). On Delta pyriforme pyriforme (Fabricius, 1775) (Hymenoptera: Vespidae: Eumeninae) from India. Uttar Pradesh Journal of Zoology 32 (3): 269-276.

Kumar, P.G., L. Kishore \& K.P.M. Shareef (2013). New distributional records of Indodynerus capitatus Gusenleitner, 2008 (Hymenoptera: Vespidae: Eumeninae). Uttar Pradesh Journal of Zoology 33(1): 8183.

Latreille, P.A. (1802-1803). Histoire Naturelle, generale et particuliere des Crustaces et des insectes, Vol. 3. Xii $+13+467$ pp. F. Dufart, Paris.

Lepeletier de St. Fargeau A.L.M. (1836). Histoire Naturelle Des Insectes. Hymenopteres, 1. Roret's Suites a Buffon, Paris.

Linnaeus, C. (1758). Systema Naturae, (10 th Ed.) Vol. 1. (Holmiae).

Saussure, H.F. de. (1852-1855). Etudes sur la famille des vespides. Vols. 1-3. V. Masson \& Cherbuliez, Paris \& Geneva.

Saussure H.F. de. (1863). Melanges Hyménoptèrologiques II. Mémoires de la Société de Physique d'Histoire Naturelle de Genève 17(1): 171-244, pl. 2.

Saussure, H.F. de. (1867). Reise der Österreichischen Fregatte Novara um die Erde in den jahren 1857, 1858, 1859., Zool. Teil,2 Band 1. Abteil A. 2. Hymenoptera. 142 pages. Wein.

Smith, F. (1852a). Descriptions of some hymenopterous insects captured in India, with notes on their economy, by Ezra T. Downes, Esq. who presented them to the honourable East India Company. Annals and Magazine of Natural History (2)9: 44-50.

Smith, F. (1852b). Descriptions of some hymenopterous insects from northern India. Transactions of the Entomological Society of London (New Series) 2(2): 45-48.

Smith, F. (1858). Catalogue of the Hymenopterous insects collected at Sarawak, Borneo; Mount Ophir, Malacca; and at Singapore, by A. R. Wallace. Journal of the Proceedings of the Linnean Society of London (Zoology) 2: 42-130.

Soika, A.G. (1961). Les lignees philetiques des Eumenes s. I. du globe (Hym. Vesp.). Verhandlungen XI Internationaler Kongress für Entomology Wien 1: 240-245.

Soika, A.G. (1981). Revisione delle specie orientali del genere Antepipona Sauss. Bollettino del Museo Civico di Storia Naturale di Venezia 32: 205-257. 
Soika, A.G. (1992). Di Alcuni Eumenidi Nuovi O Poco Noti (Hymenoptera Vespoidea). Lavori della Societa Veneziana Sciece Naturelle 17: 4168.

Spinola, M. (1806-1808). Insectorum Liguriae. Species novae aut rariores 2. Genua (Y. Gravier): 262 pp.

Vecht, J. Van Der, (1941). The Indo-Australian species of the genus Ropalidia (=Icaria) (Hym., Vespidae) (first part). Treubia 18: 103190.

Vecht, J. van der 1959 (1958). On some fabrician types of Indoaustralian Vespidae (Hymenoptera). Archives Néerlandaises de Zoologie 13, Suppl. 1: 234-247, 4 figs. Leiden.

Vecht, J. van der (1963). Studies on Indo-Australian and East Asiatic Eumenidae (Hymenoptera: Vespoidea). Zoologische Verhandelingen Leiden 60: 1-116.

Vecht, J. van der (1967). The status of certain genus-groups names in the Eumenidae (Hymenoptera, Vespoidea). Bulletin of Zoological Nomenclature 24(1): 27-33.

Vecht, J. van der (1968). The geographic variation of Polistes (Megapolistes subg. n.) rothneyi Cameron. Bijdragen tot de Dierkunde 38: 97-109.

Vecht, J. van der (1970). Further notes on Fabrician types of Vespoidea (Hymenoptera). Proceedings of the Koninklijke Nederlandse Akademie van Wetenschappen Amsterdam (Series C) 73(1): 15-24.

Wilo

zos 